\title{
Astroglial vesicular network: Evolutionary trends, physiology and pathophysiology
}

DOI:

10.1111/apha.12915

\section{Document Version}

Accepted author manuscript

Link to publication record in Manchester Research Explorer

\section{Citation for published version (APA):}

Zorec, R., Parpura, V., \& Verkhratsky, A. (2017). Astroglial vesicular network: Evolutionary trends, physiology and pathophysiology. Acta Physiologica. https://doi.org/10.1111/apha.12915

\section{Published in:}

Acta Physiologica

\section{Citing this paper}

Please note that where the full-text provided on Manchester Research Explorer is the Author Accepted Manuscript or Proof version this may differ from the final Published version. If citing, it is advised that you check and use the publisher's definitive version.

\section{General rights}

Copyright and moral rights for the publications made accessible in the Research Explorer are retained by the authors and/or other copyright owners and it is a condition of accessing publications that users recognise and abide by the legal requirements associated with these rights.

\section{Takedown policy}

If you believe that this document breaches copyright please refer to the University of Manchester's Takedown Procedures [http://man.ac.uk/04Y6Bo] or contact uml.scholarlycommunications@manchester.ac.uk providing relevant details, so we can investigate your claim.

\section{OPEN ACCESS}


Article type : Review Article

\title{
Astroglial vesicular network: Evolutionary trends, physiology and pathophysiology
}

\author{
Robert Zorec ${ }^{1,2}$ Vladimir Parpura ${ }^{3}$ \& Alexei Verkhratsky ${ }^{1,2,4,5}$ \\ ${ }^{1}$ University of Ljubljana, Institute of Pathophysiology, Laboratory of Neuroendocrinology and \\ Molecular Cell Physiology, Zaloska cesta 4; SI-1000, Ljubljana, Slovenia; \\ ${ }^{2}$ Celica, BIOMEDICAL, Technology Park 24, 1000 Ljubljana, Slovenia, \\ ${ }^{3}$ Department of Neurobiology, Civitan International Research Center and Center for Glial Biology in \\ Medicine, Evelyn F. McKnight Brain Institute, Atomic Force Microscopy \& Nanotechnology \\ Laboratories, 1719 6th Avenue South, CIRC 429, University of Alabama, Birmingham, AL 35294-0021, \\ USA \\ ${ }^{4}$ Faculty of Life Sciences, The University of Manchester, Manchester, M13 9PT, UK; ${ }^{5}$ Achucarro Center \\ for Neuroscience, IKERBASQUE, Basque Foundation for Science, 48011 Bilbao, Spain \& Department \\ of Neurosciences, University of the Basque Country UPV/EHU and CIBERNED, Leioa, Spain.
}

Send all correspondence to: robert.zorec@mf.uni-lj.si

or Alexej.Verkhratsky@manchester.ac.uk

\begin{abstract}
Intracellular organelles, including secretory vesicles, emerged when eukaryotic cells evolved some 3 billion years ago. The primordial organelles that evolved in Archaea were similar to endolysosomes, which developed, arguably, for specific metabolic tasks, including uptake, metabolic processing, storage and disposal of molecules. In comparison to prokaryotes, cell volume of eukaryotes increased by several orders of magnitude and vesicle traffic emerged to allow for communication between distant intracellular locations. Lysosomes, first described in 1955, a prominent intermediate of endo- and exocytotic pathways, operate virtually in all eukaryotic cells including astroglia, the most heterogeneous type of homeostatic glia in the central nervous system. Astrocytes support neuronal network activity in particular through elaborated secretion, based on a complex
\end{abstract}

This article has been accepted for publication and undergone full peer review but has not been through the copyediting, typesetting, pagination and proofreading process, which may lead to differences between this version and the Version of Record. Please cite this article as doi:

10.1111/apha.12915

This article is protected by copyright. All rights reserved. 
intracellular vesicle network dynamics. Deranged homeostasis underlies disease and astroglial vesicle traffic contributes to the pathophysiology of neurodegenerative (Alzheimer's disease, Huntington's disease), neurodevelopmental diseases (intellectual deficiency, Rett's disease) and neuroinfectious (Zika virus) disorders. This review addresses astroglial cell-autonomous vesicular traffic network, classified into primary and secondary vesicular network defects in diseases, targets for developing new therapies for neurologic conditions.

Key words: Vesicle network; Endocytosis; Exocytosis; Lysosome; Astrocyte; Secretory vesicle; Traffic, Rett's disease, Intellectual deficiency, Neurodegeneration.

\section{Abbreviations:}

AD - Alzheimer's disease

AQP4 - aquaporin 4 ALS - amyotrophic lateral sclerosis

ANP - atrial natriuretic peptide

AxD - Alexander's disease

BDNF - brain derived neurotrophic factor

BBB - blood-brain barrier

CNS - central nervous system

cAMP - cyclic adenosine monophosphate

EEA1 - early endosome antigen 1

ESCRT - endosomal sorting complexes required for transport

FTY 720 - fingolimod

HIV-1 - human immunodeficiency virus 1

HD - Huntington's disease

ID - intellectual deficiency

IDE - Insulin degrading enzyme

IFN- $\gamma$ - interferon- $\nu$

INCL - infantile neuronal ceroid lipofuscinosis

iPSC - inducible pluripotent stem cells

LAMP-1 - lysosome associated membrane protein 1

LC - locus coeruleus

This article is protected by copyright. All rights reserved. 
LRP1- low density lipoprotein receptor-related protein 1

Mecp2 - methyl-CpG-binding protein 2

MHC II - major histocompatibility complex II

MVB - multivesicular body

NP - Niemann-Pick disease

PPT1 - palmitoyl protein thioesterase 1

SNARE - soluble NSF attachment protein receptor

TBEV - Tick borne encephalitis virus

V-GLUT1 - vesicular glutamate transporter

ZIKV - Zika virus

XLID - X-linked forms of ID

\section{The gliocrine system: astrocytes as secretory elements of the CNS}

Astroglia are the class of neural cells, heterogeneous in form and function, primarily responsible for the homeostasis of the central nervous system (CNS). Astroglial functions also include control of synaptogenesis and regulation of synaptic connectivity, integration and synchronization of neuronal networks and the maintenance of blood-brain barrier (BBB) integrity ${ }^{1-18}$. In addition, astrocytes represent the fundamental element of defensive system of nervous tissue; insults to the brain or spinal cord trigger reactive astrogliosis, which limits the damage and facilitates post-lesion regeneration of neural networks ${ }^{3,11,13}$ although it may be also neurotoxic in some circumstances ${ }^{19}$. Moreover, astrocytes are part of the glymphatic system, regulating the convective removal of waste accumulated in the extracellular space ${ }^{20}$.

Signalling between astrocytes and other cellular elements of the CNS is mainly mediated through the release of chemical messengers. Astroglial cells secrete surprisingly large number of molecules, which include neurotransmitters and their precursors, neurohormones, trophic, plastic and growth factors, scavengers of reactive oxygen species, immunoactive molecules and pro-inflammatory factors and many more ${ }^{16,21,22}$. Mechanisms of astroglial secretion are complex and include vesicular exocytosis, diffusion through plasmalemmal channels and plasmalemmal transporters ${ }^{12,16}$. Thus astrocytes represent a gliocrine system ${ }^{22}$, responsible for regulation of the CNS microenvironment through secretion of neuroactive compounds. The role for secretory organelles is, however, substantially wider than simple export of various cargos; different types of cytosolic vesicles contribute to endocytosis and delivery of proteins to plasmalemma, whereas impairment of vesicular traffic results in multiple neuropathologies.

This article is protected by copyright. All rights reserved. 


\section{Evolution of secretory organelles}

Life forms belong to the Domains (also known as Superkingdoms) of Bacteria, Archea and Eukarya ${ }^{23}$, ${ }^{24}$. It is almost universally accepted that secretory organelles exist solely in eukaryotic cells, which notion, however, requires critical assessment. The origin and appearance of eukaryotes remains debatable ${ }^{25,26}$ and their immediate predecessors (for example, archaebacteria or eubacteria ${ }^{27}$ ) are not yet unequivocally identified. Similarly disputed is the geological age of eukaryote emergence; eukaryotic signatures have been recovered in fossils of 3 to 3.5 billion years of age ${ }^{28}$, this being substantially older than generally accepted time of eukaryote emergence $\sim 2$ billion years ago. This may indicate a very early divergence of the Domains of Life. Incidentally, the intermediate form lying in between Archea and Eukarya, the "Chronocyte", has also been suggested ${ }^{29}$.

Cytological structure of Bacteria and Archaea is relatively uncomplicated. How Eukarya, characterized by a significant degree of cellular structural complexity developed from Archaea ${ }^{30}$, is unclear, although most hypotheses assume a prokaryote-to-eukaryote transition or else an integration of an archaebacterium into a eubacterium. Conceptually, the eukaryote evolution is linked to the presence of mitochondrion-like structures and/or mitochondrial proteins. It seems, however, possible that aerobic and anaerobic eukaryotes, harbouring mitochondrial homologues of various sorts, have co-existed throughout eukaryote history ${ }^{31}$.

The hypothesis that Eukarya emerged from an ancestral Archea has recently gained interest, in particular after subcellular organelles other than mitochondria were recognised in the early life forms. Indeed, the discovery of 'Lokiarchaeota', a novel phylum, with genes encoding an array of eukaryotic signature proteins that are required for membrane plasticity supports this view ${ }^{30}$. Specifically, this ancestral Archaea expressed genes encoding proteins, which in Eukarya contribute to remodelling of cell shape and membrane deformation including phagocytosis, a form of endocytosis, where molecules or particles are transported into the cell involving vesicles pinching off the plasma membrane ${ }^{32}$. This process requires cytoskeletal elements such as actin; the Lokiarchaeum genome encodes five actin homologues with high similarity to eukaryotic actin and actin-related proteins ${ }^{30}$. Key regulators of actin cytoskeleton dynamics are small GTPases, which are essential for vesicle traffic ${ }^{33}$. A substantial presence of Ras-superfamily GTPases, which account for nearly $2 \%$ of the proteome, have been identified in Lokiarchaeota ${ }^{30}$. This Archaean phylum also contains the genes for endosomal sorting complexes required for transport (ESCRT) proteins, components of the eukaryotic multivesicular body (MVB) belonging to the endosome pathway required for the biogenesis of lysosomes, directing plasma membrane proteins for lysosomal degradation, acting in viral budding, in cytokinesis, autophagy, and other pathways ${ }^{34}$. Identification of archaeal genes involved in membrane remodelling and vesicular trafficking indicates that the emergence of subcellular organelles, resembling endolysosomal structures, was already under way before the acquisition of the mitochondrial endosymbiont ${ }^{30}$.

\section{The lysosomal network}

Lysosomes are dedicated organelles of endo- and exocytotic pathways, which operate in nearly all

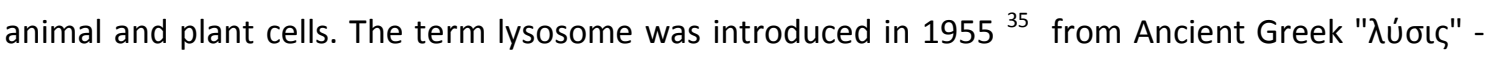
"to loosen" and "soma" - body i.e. "lytic or digestive body" since several degrading enzymes have

This article is protected by copyright. All rights reserved. 
been found in this structure ${ }^{36,37}$. To visualize this new organelle a staining method for acid phosphatase was used, and the location of these enzymes in the lysosome was confirmed by using electron microscopy ${ }^{38}$. An important insight about the degrading function of lysosomes, which contains many hydrolytic enzymes, came from the discoveries that molecules present in the extracellular space can enter the cell via endocytosis. Fragments of the labelled extracellular proteins were found localised in lysosomes ${ }^{39}$.

Until recently, it was thought that lysosomes are merely responsible for catabolism, since they contain hydrolytic enzymes. Besides degradation of biomolecules, however, the lysosome is involved in energy metabolism, in secretion, in delivery of membrane receptors to the plasma membrane, in plasma membrane repair and in cell signalling. All this is possible as lysosomes actively fuse (see Figure 1) with other cellular structures including the plasmalemma, late endocytotic vesicles, autophagosomes that haul intracellular material for degradation; in addition membrane transporters translocate metabolites, ions and soluble substrates into and out of lysosomes ${ }^{37}$. The central position of lysosome is not only linked to endocytotic entry of molecules into the cell but also to exocytotic exit of molecules (Fig. 1). Incidentally, the terms autophagy (for lysosomal degradation of material of the intracellular origin), endocytosis (for lysosomal digestion of material of the extracellular origin) and exocytosis were all introduced at a meeting in London in $1963{ }^{36}$, which followed lysosomes discovery. The complex lysosomal vesicular network is also present in astrocytes.

\section{Astrocytes and vesicle traffic}

Astrocytes actively participate in neurochemical signalling in the CNS, a property considered no longer exclusive to neurones. Astroglia express virtually all types of receptors 40,41 to neurotransmitters and neuromodulators linked to the second messenger excitability involving cytosolic ionic signals ${ }^{42-45}$ and cyclic adenosine monophosphate (cAMP) pathways ${ }^{22,46}$. Astrocytes are also capable of secreting numerous signalling molecules.

Neurochemical signalling involves vesicle-related processes and the first observation of these functional subcellular structures in astrocytes was made over 100 years ago by microscopic studies conducted by Hans Held ${ }^{47}$ and Jean Nageotte ${ }^{48}$, who both proposed that glial cells act as secretory entities in the CNS. Existence of secretory organelles in astroglia has been confirmed by advanced biophysical, electrophysiological and quantitative high-resolution optical microscopy studies ${ }^{16,49,50}$. In contrast to vesicle-based fast neuronal signalling, vesicular regulated exocytosis in astrocytes occurs in a much slower time-domain, with temporal characteristics closely related to the slow CNS processes including neurodevelopmental plasticity, memory formation and homeostatic metabolic support; all these being strongly influenced by the relatively slow delivery of metabolic precursors for morphological and functional CNS plasticity ${ }^{51,52}$.

The integrating role of glial communication in the CNS resembles, to some extent, the function of the endocrine system, a master regulator of bodily functions, which operates substantially slower than rapid, often sub-millisecond, synaptic neuronal signalling. Therefore, astroglia were proposed to constitute the gliocrine system within the CNS ${ }^{16,22}$. Another similarity between the endocrine and the gliocrine systems lies in the manner of signalling molecules delivery to the appropriate targets. Hormones are transported by blood circulation, while gliosignalling molecules, secreted by astroglia into the interstitium, can be convectively transferred by the recently described glymphatic apparatus

20. Thus, astroglial vesicular networks contribute to the tissue-wide array of processes, all fundamental to normal and pathological CNS conditions.

This article is protected by copyright. All rights reserved. 


\section{Astroglial endocytosis}

Endocytosis consists of many processes, and contributes to a multitude of cellular functions including uptake of extracellular nutrients, regulation of cell-surface receptor presence, which shapes the plasmalemmal signalling landscape, and antigen presentation ${ }^{32}$. Astrocytes are facultative antigen presenting cells ${ }^{53}$, especially during pathological conditions, when they become reactive.

Astrogliosis, an active defensive response of astrocytes is associated with various diseases/disorders; astrogliotic remodelling facilitates resolution of the pathology, although under some circumstances it may be maladaptive and deleterious ${ }^{13,19}$. Discrimination of stages of astrogliosis is difficult, since there is a gradient of changes in structure, expression of genes and function. However, exposure of astrocytes to interferon- $\gamma$ (IFN- $\gamma$ ) induces the expression of major histocompatibility complex II (MHC II) molecules. These molecules traffic within astrocytes by endolysosomal vesicles along the cytoskeletal intermediate filaments ${ }^{53}$ and reach the plasmalemmal surface following the fusion of these organelles with the plasma membrane. Lysosomal destination for fusion with the plasma membrane is to some degree determined by their previous interaction with autophagosomes ${ }^{37}$ and is regulated by $\beta$-adrenergic receptor signalling, which inhibits the expression of MHC II molecules in astrocytes ${ }^{54,55}$. Whether this process provides toxic or beneficial effects in the pathological process in the damaged tissue remains to be determined.

Extracellular debris removal by astroglial endocytosis

The removal of waste materials and debris from the extracellular space is in part the function of endocytosis coupled with the convective flow of the glymphatic system, an important clearance mechanism, depending on aquaporin 4 (AQP4) water channel ${ }^{56-58}$. Although the position of AQP4 in the brain appears to be important in determining water transport in the brain ${ }^{59}$, it is still unclear how AQP4 participates in the convective flow of extracellular solution through the brain and spinal cord parenchyma, which appears key in ensuring CNS homeostasis and contributes to pathologic conditions as occurring in cerebral ischemia, neurotrauma, cytotoxic oedema, epilepsy, Parkinson's and Alzheimer's diseases, in which the BBB is compromised ${ }^{60-62}$. Debris that accumulates in the CNS due to transfer from the systemic circulation through the BBB or due to pathological events within the CNS itself, coupled to diffusion, fluxes along the relatively long tortuous extracellular space of the brain interstitium and may be taken into astroglial vesicle network by endocytosis.

Astroglial endocytic and lysosomal network can be fundamental for the removal of cellular detritus and toxic macromolecules both in physiological and pathological context. In a multitude of diseases/conditions associated with myelin destruction, which include multiple sclerosis, progressive multifocal leukoencephalopathy, metachromatic leukodystrophy and subacute infarct, astrocytes accumulate myelin debris by means of cell surface scavenger receptor low density lipoprotein receptor-related protein 1 (LRP1) receptor-mediated endocyosis ${ }^{63}$. Myelin fragments were rapidly (within $120 \mathrm{~min}$ ) translocated from endosomes to lysosomes, where they underwent degradation. Astrocytes can remove myelin in physiological context, for example during developmentally regulated shortening of optic nerve in Xenopus laevis ${ }^{64}$. In Drosophila larvae astroglial cells act as primary phagocytotic elements critical for the removal of neurites during neuropil development ${ }^{65}$ as

This article is protected by copyright. All rights reserved. 
well as pruning of axons in developing, mushroom bodies ${ }^{66}$, with the removed material entering edno-lysosomal degrading pathway. Astrocytes also employ endocytosis for the accumulation of signalling molecules, for example neurokinin $\mathrm{B}^{67}$ or pro-brain derived neurotrophic factor (BDNF) ${ }^{68}$.

In neurotrauma, for example, cytoplasmic proteins exit into the extracellular space. This may result in additional toxicity, with these proteins exerting further damaging effects on neighbouring cells. The capacity of internalization of $\mathrm{S} 100 \mathrm{~B}$, a protein secreted by astrocytes ${ }^{69}$, was studied recently ${ }^{70}$. Fluorescently labelled S100B (S100B-Alexa Fluor ${ }^{\circ} 488$ ) was added to the cultured astrocytes and cells were monitored by time-lapse confocal microscopy. The S100B was found to enter cells, with subsequent trafficking with endocytotic vesicles. The entry of S100B-Alexa ${ }^{488}$ involved, at least in part, the "scavenger receptor" RAGE, since pre-treatment with anti-RAGE antibody partially prevented the uptake of S100B-Alexa Fluor 488 . Endocytotic uptake of S100B-Alexa Fluor 488 was also suppressed by a dynamin inhibitor Dynole 34-2. As described previously ${ }^{71}$, endolysosomal traffic exhibits directional and non-directional vesicle mobility, and this was also observed for endocytotic vesicles taking up S100B-Alexa Fluor $488^{70}$. Directional mobility of S100B-Alexa Fluor 488 -positive vesicles increased over time as did the co-localization of this protein with a lysosomal marker, indicating the transport of the internalized protein into this compartment ${ }^{70}$.

\section{Exocytotic vesicles in astroglia}

Although astroglial vesicle-mediated release of chemical messengers is well documented, this mechanism, however, is distinct from that operational in neurones, especially when the kinetics is considered ${ }^{16,49,72,73}$. Following the pioneering studies which revealed astroglial release of glutamate in a $\mathrm{Ca}^{2+}$-dependent manner ${ }^{74}$, the role of vesicular secretion of gliosignalling molecules was analysed in vesicles containing fluorescently labelled atrial natriuretic peptide (ANP) ${ }^{50}$ and by monitoring membrane capacitance, a parameter linearly related to membrane area ${ }^{75}$ and sufficiently sensitive to detect unitary vesicle fusion/fission events in real-time in isolated ${ }^{76,77}$ and also in astrocytes in tissue slices ${ }^{78}$. While there has been comprehensive coverage on the size and nature of vesicles in astrocytes elsewhere ${ }^{10,16,18}$, using electron microscopy and fluorescence markers ${ }^{68,79-82}$. Here, we focus on a recent study, where the super-resolution fluorescence microscopy was combined with the high-resolution membrane capacitance monitoring ${ }^{83}$, compellingly demonstrated the existence of two populations of secretory vesicles (distinct in their size) in cultured and freshly isolated rat astrocytes. Small vesicles ( $70 \mathrm{~nm}$ in diameter) mainly contain amino acids glutamate (based on labelling of the vesicular glutamate transporter 1; V-GLUT1) and D-serineand/or peptides (brain derived neurotrophic factor - BDNF and ANP), whereas ATP and some peptides are present mainly in larger ( $200 \mathrm{~nm}$ in diameter) lysosome-associated compartments (marked by antibody against the lysosomal associated membrane protein LAMP-1 and by quinacrine (which binds to adenine nucleotides), as was already reported previously ${ }^{84}$. This separation of vesicular populations was not dependent on animal age, since similar results were obtained in astrocytes deriving from post-natal as well as from adult animals. The larger vesicles that contain peptides and ATP may well be generated by the fusion of peptidergic vesicles that arise from the Golgi cisternae with some endosomes and/or lysosomes. Vesicles of all sizes in astrocytes interact with the plasma membrane, as was monitored by discrete increases in membrane capacitance. As was already noted for

This article is protected by copyright. All rights reserved. 
endocrine cells ${ }^{85}$, transient exocytotic fusions were more abundant than the full-fusion exocytotic events, especially after stimulation of cells, which facilitates conversion of transient fusion events to full-fusion predominantly in larger vesicles ${ }^{83}$. This vesicle size-dependent mechanism of unitary exocytotic events is not due to a different density of SNARE molecules in larger and smaller vesicles ${ }^{86}$, but it more likely reflects vesicle size-dependent stability of fusion pores, which appear more stable in smaller vesicles ${ }^{87}$.

\section{Regulation of vesicle network dynamics in astrocytes}

First measurements of single vesicle peptidergic release from astrocytes ${ }^{50}$, found that individual vesicles exhibit high mobility with elongated directional and contorted nondirectional tracks. This was further corroborated by quantification of vesicle paths ${ }^{88}$. Similar dual-modal vesicle mobility has been observed in other cell types, such as chromaffin and neuroendocrine cells ${ }^{88-91}$. In contrast to other cell types, however, vesicle traffic in astrocytes exhibited a remarkable regulation by changes in $\left[\mathrm{Ca}^{2+}\right]_{\mathrm{i}}{ }^{92,93}$. Increase in $\left[\mathrm{Ca}^{2+}\right]_{\mathrm{i}}$ reduced mobility of peptides- and ATP-containing vesicles ${ }^{71}$, while increasing the mobility of vesicles carrying amino acids and labelled by VGLUT1 ${ }^{94}$. Recycling vesicles, which take-up extracellular markers (such as antibodies that bind to vesicle cargo or vesicle luminal markers) and subsequently release them by exocytosis, also demonstrate similar vesicle dynamics, both in cultured astrocytes ${ }^{95}$ and in the brain slices ${ }^{96}$. Increase in astroglial $\left[\mathrm{Ca}^{2+}\right]_{\mathrm{i}}$, arrests movements of recycling vesicles ${ }^{95}$. These vesicle type dependent, regulatory mechanisms may well change in pathologic conditions ${ }^{2,92}$.

\section{Astroglia as a central element of neuropathology}

Astroglia contribution to neuropathology is multifaceted and most likely disease-specific. The very nature of astrocytes as homeostatic cells makes them central elements in neural tissue response to various insults. In the context of neurological diseases astroglia may undergo pathological remodelling (for example, in Alexander disease - AxD), degeneration with loss of function (in psychiatric diseases or at the early stages of neurodegenerative diseases such as amyotrophic lateral sclerosis - ALS, or Alzheimer's disease - AD) or reactive astrogliotic remodelling instigated by neurotrauma or accumulation of extracellular pathological protein deposits such as Levy bodies of senile plaques ${ }^{11,13,19,21,40,97-102}$. These principal pathological metamorphoses can develop separately or in combination, and moreover distinct astrogliopathological changes may emerge at different stages of neurological disorders. Degeneration and atrophy of astrocytes, which is manifested by a decrease in the number of cells and dwindling of their morphological profiles is often associated with compromised glutamate clearance that seems to be a converging point in many diseases associated with glutamate neurotoxicity. The impaired astroglial glutamate uptake plays a critical role in neurological disorders with broad clinical manifestations, which include ALS, Wernicke's encephalopathy, Huntington's disease (HD) and some psychiatric disorders ${ }^{3,103}$. Astrogliotic response is a similarly widespread feature of neuropathology ${ }^{98}$. Astrogliosis represents a conserved defensive reprogramming of astroglial cells, which involves complex biochemical and functional remodelling and produces multiple reactive cellular phenotypes. Reactive astrocytes boost neuroprotection and are critical for post-lesion regeneration of the nervous tissue; inhibition of

This article is protected by copyright. All rights reserved. 
astroglial reactivity usually exacerbates neuropathology. The common denominator of astrogliopathological changes are associated with morphological remodelling aimed towards atrophy or hypertrophy ${ }^{104,105}$. These relatively rapid morphological changes may involve modified vesicular trafficking ${ }^{46,92}$; similarly, both astrodegeneration and astroglial reactivity result in changes in astroglial vesicular intracellular networks.

\section{Vesicular dysfunction in neurologic diseases}

Vesicle traffic associates with numerous functions of astrocytes including regulation of the plasma membrane density of receptors, pumps, transporters, is involved in changes in morphological plasticity and in cell degradation pathways. Impairment of the vesicle network dynamics hence may contribute to astrogliopathies ${ }^{92}$.

Primary and secondary vesicle network defects

In relation to vesicle network disturbances, in principle, there are two main groups of disorders, depending on the defect within the astroglial vesicular network. First, vesicle traffic may be primarily affected due to altered regulation of vesicle mobility including altered association of vesicles with the cytoskeletal elements, mutated cytoskeletal elements, and/or disturbances in the vesicle membrane merger. These alterations are becoming uncovered only recently when experimental approaches enabling direct monitoring of vesicle traffic at single vesicle level in real-time in astrocytes have been introduced $^{76,88,106}$ and due to advanced genetic and posttranslational tubulin studies ${ }^{107}$. Examples of neurological diseases with primary vesicle network defects are listed in Table 1. Impaired vesicle mobility may result from alterations in cytoskeleton fabrics. Such alterations accompany reactive gliosis with overexpressed intermediate filaments ${ }^{108}$. Similarly, cytoskeleton is impaired in AxD, associated with sporadic mutations of glial fibrillary acidic protein ${ }^{109}$. Unstable microtubules contribute to the Rett's disease ${ }^{110}$. General defects in vesicle traffic possibly are observed in neurodegeneration including $A D^{111}, \mathrm{HD}^{112}$, and in $A \mathrm{LS}^{113,114}$. Mutated regulatory proteins affect vesicle dynamics ${ }^{115}$ in intellectual deficiency (ID) ${ }^{116}$. Vesicle dynamics may be also altered by virus infection such as the Tick borne encephalitis virus (TBEV) infection ${ }^{117}$ or autoimmune Devic's disease (neuromyelitis optica) ${ }^{118,119}$ where vesicle dynamics of AQP4 water channel is affected ${ }^{120,121}$. Alterations in vesicle dynamics may develop as side effects of medication, for example, in multiple sclerosis treated with FTY $720{ }^{122}$ or when using ketamine, an anaesthetic and antidepressant ${ }^{106}$, which also affects vesicle merger with the plasma membrane ${ }^{123}$.

The other vesicle network defects, termed secondary, are associated with abnormalities of carried cargo. Enzymatic deficits result in impaired processing of metabolic intermediates, which are transported in vesicles leading to accumulation of the non-degraded cargo in the vesicular compartment that may disrupt (jam) the vesicle network as a whole (Figure 1). In support that the vesicle network defects are of two kinds, primary and secondary, are experiments, where a combination of cytoskeleton alteration and an enzymatic deficit was introduced to study infantile

This article is protected by copyright. All rights reserved. 
neuronal ceroid lipofuscinosis (INCL), an inherited neurodegenerative disorder, caused by mutations in the lysosomal hydrolase, palmitoyl protein thioesterase 1 (PPT1), revealed that if both the intermediate filament cytoskeleton (deleting GFAP and vimentin) and the the PPT1 were impaired, the INCL progressed more rapidly ${ }^{124}$.

Malfunction of hydrolitic enzymes, such as PPT1, impairs lysosomal degrading pathway; this impairment lies at the core of extended (more than 60 members) family of lysosomal storage diseases ${ }^{125,126}$. Roughly two thirds to three quarters of lysosomal storage diseases are neuropathic ${ }^{127}$. Neurological disorders resulting from lysosomal pathology include neuronal ceroid lipofuscinoses (or Batten disease), Krabbe disease, Gaucher disease, Sandhoff disease, Niemann-Pick (NP) type C, Tay-Sachs disease, etc. ${ }^{128}$. In Tay-Sachs disease there is a deficiency of hexosaminidase A, a vital lysosomal hydrolytic enzyme, degrading glycolipids ${ }^{129}$. As a result, these lipids accumulate, and this intracellular accumulation affects normal cell function and interferes with normal tissue processes, eventually leading to premature cell death. Sandhoff disease is characterized by deficiency of hexosaminidases $A$ and $B$, resulting in excessive lysosomal accumulation of GM2 gangliosides and oligosaccharides containing glucosamine residues ${ }^{130}$. The Niemann-Pick (NP) diseases are a subfamily of lipid storage disorders in which harmful quantities of lipids or fatty acids accumulate in the liver, bone marrow, lungs, spleen, and CNS. In the type A of NP diseases there is a deficiency of sphingomyelinase ${ }^{131}$, hence sphingomyelin accumulates in lysosomes, leading to the enlargement of cells. The Gaucher disease reflects upon deficiency of acid-beta-glucosidase, leading to accumulation of glucosylceramide ${ }^{132}$, whereas Krabbe disease is associated with the deficiency of $\beta$ -

galactocerebrosidase ${ }^{127}$. In the context of lysosomal storage diseases, astrocytes demonstrate either reactive phenotypes or apoptotic death, both of which possibly associate with abnormalities of the lysosomal network ${ }^{127}$. Astroglial reactive remodelling sometimes occurs at the early pathological stages preceding (and possibly precipitating) neuronal death; such an early activation is observed, for example, in juvenile Batten disease ${ }^{133}$. Considerable lysosomal pathology was observed in astrocytes in the context of multiple sulfatase deficiency that cause severe neurodegeneration. Deficient astroglial lysosomal network affects autophagy and is linked to decreased neuronal survival ${ }^{134}$.

In contrast to secondary vesicle network impairments, vesicle dynamics in primary network defects, may be directly affected by changes in cytoskeleton along which vesicles are transported. As mentioned previously, vesicles exhibit directional and non-directional mobility. The former depends on intact cytoskeleton ${ }^{108}$ and impairments in the linking of vesicles to cytoskeleton as well as changes in cytoskeleton may lead to pathology. This means that vesicle network dynamics may be a target for treatments.

\section{Neurotropic viruses use endocytosis to enter astrocytes}

The rise of Zika virus (ZIKV) epidemic in the Central and South Americas enticed refreshed interest into how the virus, linked with microcephaly (severe under-development of the cerebral cortex in newborn babies from infected mothers ${ }^{135}$ ), instigates this neurodevelopmental disorder. As shown previously the tick-borne encephalitis virus (TBEV), a human pathogen that causes neuroinfections in

This article is protected by copyright. All rights reserved. 
Europe and Asia ${ }^{136-138}$, infects astroglia, after entering astrocytes by endocytosis ${ }^{117}$. The TBEV, as well as ZIKV are members of the Flaviviridae family ${ }^{135,139}$. A similar mechanism of entry into astrocytes, (although it is yet to be fully characterised) underlies ZIKV neurotropism. Again, similar mechanism underlies astroglial infection with human immunodeficiency virus 1 (HIV-1), which enters astroglia by endocytosis, however the HIV-1 virus seems to be effectively destroyed in the astroglial lysosomal pathway ${ }^{140}$.

Mechanisms of TBEV entry into rodent astrocytes are complex ${ }^{117}$. First, to invade the CNS, a neurotropic virus must negotiate the $\mathrm{BBB}$, which protects the CNS tissue from the direct ingress of viruses circulating in the blood ${ }^{138,141}$. Astrocytes are a key component of the $\mathrm{BBB}$, with astroglial endfeet providing almost complete coverage of the intracranial vasculature. Astrocytes are positioned between synapses and blood vessels, contributing to neurovascular coupling ${ }^{142,143}$. Infection with TBEV does not affect astroglial viability; to the contrary, astrocytes likely serve as a reservoir for TBEV supporting re-infection ${ }^{117}$. Second, preferential viral infection of astroglia likely reflects the fact that astrocytes provide a favourable environment for virus replication, possibly because since they are the site with a special adaptation of glycolysis. Aerobic glycolysis, characteristic for astroglia, also exists in rapidly dividing cells and in cells undergoing plastic morphological changes, despite the presence of adequate levels of oxygen, a phenomenon known as "the Warburg effect" ${ }^{144}$. This form of metabolism is far from being efficient for ATP production; however, it provides biosynthetic intermediates thus being advantageous for developing and growing tissues ${ }^{145}$. Aerobic glycolysis, primarily taking place in astrocytes in the CNS, is operative during neurodevelopment and even in adulthood in some areas of the $\mathrm{CNS}^{146}$. Therefore, this property of astrocytes may be associated with the preferential infection of astrocytes by neurotropic viruses, such as ZIKV.

Intra-astrocytic traffic of TBEV within the endosomal system was monitored in real-time ${ }^{117}$. As depicted on Figure 2, TBEV particles associate with early endosomes and later, during the postinfection time, also with lysosomes as revealed by co-localization of TBEV particles with endosomal (early endosome antigen 1, EEA1) and lysosomal LAMP1 markers. Similarly to secretory vesicles ${ }^{88}$, endocytosed TBEV-containing vesicles exhibit two forms of mobility in living astrocytes, directional and non-directional. The former likely reflects vesicular transport with protein motors along the cytoskeletal elements, such as microtubules, actin and intermediate filaments, including astrogliaspecific glial acidic fibrillary protein (GFAP) ${ }^{108}$. In contrast, the mobility of non-directional vesicles is determined by free diffusion ${ }^{88}$. Prolongation of the post-infection time not only increased the number of TBEV particles within an astrocyte, but it also resulted in increased TBEV particle mobility 117.

Endocytosis was recently confirmed to be the mechanism of ZIKV infection of astrocytes and microglia ${ }^{147}$. The membrane protein Axl, a member of the Tyro3 Axl Mer (TAM) family of proteins, exhibiting tyrosine kinase receptor activity, regulating innate immunity and the removal of apoptotic cells ${ }^{148}$, plays a role in targeting glia ${ }^{147}$. Since $A x l$ is abundantly expressed in glial but not in neural progenitor cells, this indicates a preferential cellular tropism for ZIKV infection ${ }^{147}$. Future

This article is protected by copyright. All rights reserved. 
experiments should aim to confirm that neurovirulence of ZIKV and other flaviviruses is associated mainly with astroglia, including radial glia, which are fundamental for the development of the human neocortex, which involves the activity of locus coeruleus $(L C)^{149}$. The release of noradrenaline form LC neurones activates aerobic glycolysis in astrocytes, monitored as an increase in cytosolic glucose concentration ${ }^{150}$, leading to the production of L-lactate ${ }^{151}$. The increased levels of L-lactate feed back to the LC neurons ${ }^{152}$, an interesting glio-neuronal communication where L-lactate serves as a signal.

\section{Neurodegeneration and vesicle traffic deficits}

Neurodegeneration starts decades before clinical presentation, and may involve defective vesicle traffic. The initial changes might be small, but over a long time-period, significant transformations of cells and, subsequently, of tissue function develop. Small initial changes have been detected in astrocytes from 3xTg-AD mice, an animal model for $A D$, expressing three mutant genes for amyloid precursor protein ( $\left.\mathrm{APP}_{\mathrm{Swe}}\right)$, presenilin 1 ( $\mathrm{PS}_{\mathrm{M} 146 \mathrm{~V}}$ ) and microtubule-associated protein Tau (Tau $\mathrm{T}_{\mathrm{P} 301 \mathrm{~L}}$,

${ }^{153}$. These astrocytes, which (according to the disease model genetic design) express only the PS $1_{\mathrm{M} 146 \mathrm{~V}}$ mutation, exhibit impaired vesicle traffic ${ }^{111}$. Mobility of peptidergic and endolysosomal vesicles in astrocytes, isolated during early pre-symptomatic state, revealed that spontaneous as well as stimulated, $\mathrm{Ca}^{2+}$ - dependent, vesicle mobility was diminished. The impaired vesicle traffic was observed also in wild type rat astrocytes transfected with familial $A D$-associated mutated PS1 $1_{\mathrm{M} 146 \mathrm{~V}}$ gene. Eventually, altered properties of vesicle mobility may result in reduced peptide secretion, contributing to the development of neurodegeneration ${ }^{111}$. Moreover, a recent study where mutated huntingtin caused impaired peptidergic secretion in $\mathrm{HD}^{112}$, is supporting the view that vesicle traffic defects may lead to neurodegeneration ${ }^{92}$.

In addition to a reduced capacity of vesicular release of peptidergic and various chemical messengers from astrocytes, other vesicle-based mechanisms might contribute to the evolution of neurodegeneration. A prominent histopathological sign of $A D$ is the extracellular accumulation of $\beta$ amyloid, which may be associated with a reduced capacity for removal or degrading mechanisms ${ }^{154}$. An important factor that may decrease $\beta$-amyloid deposits is the release of proteolytic enzymes from exocytotic lysosomes, which degrade the $\beta$-amyloid peptide in the extracellular space. Insulin degrading enzyme (IDE) is such an enzyme, secreted from neurones in the healthy brain ${ }^{155}$. In astrocytes the secretion of IDE can be increased by an autophagy-dependent way by statins, a process likely leading to statin-induced degradation of extracellular $\beta$-amyloid peptide $A \beta 40$, which depends on IDE secretion from primary astrocytes ${ }^{156}$. Therefore, it appears, that in $A D$ the function of IDE secretion by astrocytes is reduced in comparison to astrocytes in healthy subjects, consequently leading to increased deposits of $\beta$-amyloid. The mechanism of reduced secretion of IDE in $A D$ is possibly mediated by an impaired interaction between autophagosomes and lysosomes ${ }^{154}$, an interaction needed to facilitate lysosomes to become competent for exocytosis ${ }^{37}$. The reduced capacity for release of IDE by astrocytes may mirror a general vesicle traffic defect associated with a lysosomal involvement in injury repair in astrocytes ${ }^{157}$.

This article is protected by copyright. All rights reserved. 
In the vicinity of plaques and $\beta$-amyloid deposits astrocytes attain a reactive phenotype with overexpressed intermediate filaments ${ }^{158}$. Astrocytes exposed to IFN- $\gamma$, a pro-inflammatory cytokine, start to expresses in their surface membrane MHC-II molecules, turning astrocytes into antigen-presenting cells. These molecules are delivered to the plasma membrane by endolysosomes ${ }^{53,159}$. Vesicle delivery of MHC-II molecules to the plasma membrane involves a cytoskeletal network that exhibits upregulated intermediate filaments, a characteristic of astrogliosis ${ }^{13}$. However, microtubules ${ }^{160,161}$, actin ${ }^{162}$ and their motor proteins ${ }^{160,163}$ have all been reported to play a role in MHC-II-vesicle traffic. Up-regulation of cytoskeletal structures, in particular intermediate filaments, speeds up vesicle mobility and makes antigen presentation more efficient ${ }^{53}$. Noradrenaline, released from LC neurones is an endogenous suppressor of antigen presentation by astrocytes ${ }^{54}$; whether this inhibition involves reduced vesicle traffic, remains to be studied.

\section{Neurodevelopment-related diseases and vesicle traffic}

Vesicle traffic is strongly involved in neurodevelopment ${ }^{164}$, for example, by regulating cell migration during the neocortex formation ${ }^{165}$. Thus, when a neurotoxic attack or a viral infection impairs vesicle dynamics, neurodevelopmental defects (such as the microcephaly associated with ZIKV infection) may follow ${ }^{135}$.

In neurodevelopmental diseases, such as in intellectual deficiency (ID), a form of mental retardation characterised with low $(<85) \mathrm{IQ}$, vesicle traffic disturbances may be the key cellular defect. The only manifest sign in nonspecific ID is a reduced cognitive potential, which when presented together with other clinical signs and symptoms may compose a syndrome (e.g., Down syndrome), or may be associated with mitochondrial, developmental or metabolic deficits ${ }^{166}$. Symptoms of X-linked forms of ID (XLID), which appear early in life, are affecting a fair number of subjects; XLID is present in around $2 \%$ of the population ${ }^{167}$. One of the first mutated genes discovered in patients with XLID is GDI1 ${ }^{168}$, which encodes the $\alpha \mathrm{GDI}$, a regulatory protein of monomeric GTP-ases, such as the family of Rab proteins. The $\alpha$ GDI protein retrieves the inactive, GDP-bound form of Rab proteins, from the membrane. Rab GTPases are important vesicle traffic regulators ${ }^{169}$. Therefore, when the causal role for GDIl mutated gene in ID was identified, this suggested that vesicular traffic in neuronal synapses is affected ${ }^{170,171}$. Astrocytes express $\alpha$ GDI, and vesicle traffic in astrocytes carrying a mutation in GDI revealed an impaired vesicle phenotype; vesicle directionality index was reduced, revealing a less efficient coupling of vesicles to the cytoskeleton ${ }^{116}$. These results are consistent with previously published data, where the role of mutated Rab 4 and Rab 5 monomeric GTP-ases, both regulated by $\alpha$ GDI protein, were studied (Potokar et al., 2012). How the impaired endolysosomal traffic affects the function of astrocytes in ID remains to be clarified.

Abnormal astrocytic vesicle traffic underlies another autistic spectrum disorder, the Rett's syndrome, a rare X-linked neurodevelopmental disease ${ }^{110}$. Mutations in the methyl-CpGbinding protein 2 (Mecp2), encoding a multifunctional protein that binds to methylated DNA, acting as a transcriptional regulator are believed to be responsible. When Mecp2 is reexpressed specifically in astrocytes in the Mecp2-null mice, locomotion and anxiety levels

This article is protected by copyright. All rights reserved. 
were significantly improved, respiratory abnormalities were restored to a normal pattern and lifespan was greatly prolonged compared with knock-out mice ${ }^{172}$. Microtubule-dependent vesicle transport is altered in Mecp2-deficient astrocytes isolated from newborn Mecp2deficient mice and from human MECP2 p.Arg294* iPSC-derived astrocytes ${ }^{110}$. Administration of microtubule-stabilizing drug (Epothilone D), that passes BBB restored microtubule dynamics in Mecp2-deficient astrocytes and in human MECP2 p.Arg294* iPSCderived astrocytes in vitro. Therefore, drugs that target not only the fusion/fission of vesicles with the plasma membrane as does ketamine, but also molecules that target the integrity of the cytoskeleton are valid targets for new innovative treatments of impaired vesicle networks to be used in future therapies.

\section{Vesicle network dynamics, a target of drugs for treating neurological disturbances}

Several drugs, currently used to treat neurological disease, have an effect on astrocytic vesicle dynamics. Vesicle mobility in astrocytes is decreased by fingolimod or FTY720 ${ }^{122}$. This drug (Gilenya, Novartis), which is hydrophobic in nature, accumulates in the white matter in the CNS and is used for the treatment of multiple sclerosis ${ }^{173}$. The marketing authorization holder claims that the mechanism of action of this drug is an inhibition of the egress of lymphocytes into the CNS in its phosphorylated form, acting via the sphingosin 1 receptor (SP1R) ${ }^{174}$. However, this molecule also acts in the unphosphorylated form directly on astrocytes where it affects astrocytic vesicle dynamics ${ }^{122}$ and likely also antigen presentation by astrocytes, that associates with neuroinflammation ${ }^{53}$. FTY 720 treatment revealed that traffic of all vesicle types studied were affected ${ }^{122}$, hence this drug may modulate the release of other proinflammatory factors from astrocytes, including eicosanoids, which are released in the CNS by an ATP-dependent mechanism ${ }^{175}$. Regulated release of ATP from astrocytes ${ }^{84}$ participates in the neuroinflammatory CNS states and alterations of traffic of ATP carrying organelles may additionally affect neuroinflammatory response in diseased conditions.

Another established drug, ketamine, an anaesthetic and an antidepressant, affects the vesicle traffic and BDNF release from astroglia ${ }^{106}$. High-resolution membrane capacitance measurements revealed that in the presence of clinically relatively low concentrations, ketamine induces fusion pores to enter into a stable, narrow flickering state ${ }^{123}$. In the presence of ketamine, the fusion pore attains a diameter that is too narrow to permit the discharge of the peptides contained in the vesicle lumen 106,176 . These results indicate that the fusion pore, an intermediate stage of the secretory vesicle traffic, is a target for therapy.

\section{Conclusions}

Vesicular network consists of many pathways, where endocytotic and exocytotic vesicles merge and give rise to new vesicles, essentially intersecting with the lysosome, present in nearly all eukaryotic cells including astrocytes. Thus lysosomes, being at the crossroad of many vesicle-based processes, not only contribute to their classically asigned function - degradation of molecules - but instead, control the whole vesicle network, contributing to important subcellular physiological events, including the modulation of the metabolic and signalling capacity of astrocytes, as well as determining the morphological plasticity and adaptability to pathologic changes. By understanding more fully the mechanisms of vesicle network traffic and the interaction of vesicles with the

This article is protected by copyright. All rights reserved. 
cytoskeleton, at various stages, from how endocytotic mechanisms prime some lysosomes to becoming exocytotic vesicles, to how vesicles containing peptidergic cargo, emerging from Golgi, interact with antigen presentation systems and phagocytosis. Clearly, as addressed in this review, all these processes may well form the basis for neurological dysfunction and represent targets for development of new therapies.

\section{Acknowledgements}

This work was supported by grants P3 310, J3 6790, J3 6789 and J3 7605 from the Slovenian Research Agency (ARRS), CipKeBip, COST Action BM1002, EU COST Action CM1207 - GLISTEN (to RZ). VP's work is supported by the National Institutes of Health (The Eunice Kennedy Shriver National Institute of Child Health and Human Development award HD078678 to VP).

\section{Conflicts of Interest}

The authors declare no conflict of interest.

\section{References}

1. Verkhratsky, A, Nedergaard, $M$ : The homeostatic astroglia emerges from evolutionary specialization of neural cells. Philos Trans R Soc Lond B Biol Sci, 371, 2016.

2. Potokar, M, Stenovec, M, Kreft, M, Gabrijel, M, Zorec, R: Physiopathologic dynamics of vesicle traffic in astrocytes. Histol Histopathol, 26: 277-284, 2011.

3. Verkhratsky, A, Zorec, R, Rodriguez, JJ, Parpura, V: Astroglia dynamics in ageing and Alzheimer's disease. Curr Opin Pharmacol, 26: 74-79, 2016.

4. Abbott, N, Rönnbäck, L, Hansson, E: Astrocyte-endothelial interactions at the blood-brain barrier. Nat Rev Neurosci, 7: 41-53, 2006.

5. Christopherson, K, Ullian, E, Stokes, C, Mullowney, C, Hell, J, Agah, A, Lawler, J, Mosher, D, Bornstein, P, Barres, B: Thrombospondins are astrocyte-secreted proteins that promote CNS synaptogenesis. Cell, 120: 421-433, 2005.

6. Haseloff, RF, Blasig, IE, Bauer, HC, Bauer, H: In search of the astrocytic factor(s) modulating blood-brain barrier functions in brain capillary endothelial cells in vitro. Cell Mol Neurobiol, 25: 25-39, 2005.

7. Haydon, P: GLIA: listening and talking to the synapse. Nat Rev Neurosci, 2: 185-193, 2001.

8. Martin, D: Synthesis and release of neuroactive substances by glial cells. Glia, 5: 81-94, 1992.

This article is protected by copyright. All rights reserved. 
9. Nedergaard, M, Ransom, B, Goldman, S: New roles for astrocytes: redefining the functional architecture of the brain. Trends Neurosci, 26: 523-530, 2003.

10. Parpura, V, Baker, B, Jeras, M, Zorec, R: Regulated exocytosis in astrocytic signal integration. Neurochem Int, 2010.

11. Parpura, V, Heneka, MT, Montana, V, Oliet, SH, Schousboe, A, Haydon, PG, Stout, RF, Jr., Spray, DC, Reichenbach, A, Pannicke, T, Pekny, M, Pekna, M, Zorec, R, Verkhratsky, A: Glial cells in (patho)physiology. J Neurochem, 121: 4-27, 2012.

12. Parpura, V, Zorec, R: Gliotransmission: Exocytotic release from astrocytes. Brain Res Rev, 63: 83-92, 2010.

13. Pekny, M, Pekna, M, Messing, A, Steinhauser, C, Lee, JM, Parpura, V, Hol, EM, Sofroniew, MV, Verkhratsky, A: Astrocytes: a central element in neurological diseases. Acta Neuropathol, 131: 323-345, 2016.

14. Sultan, S, Li, L, Moss, J, Petrelli, F, Casse, F, Gebara, E, Lopatar, J, Pfrieger, FW, Bezzi, P, Bischofberger, J, Toni, N: Synaptic Integration of Adult-Born Hippocampal Neurons Is Locally Controlled by Astrocytes. Neuron, 88: 957-972, 2015.

15. Tao-Cheng, J, Nagy, Z, Brightman, M: Tight junctions of brain endothelium in vitro are enhanced by astroglia. J Neurosci, 7: 3293-3299, 1987.

16. Verkhratsky, A, Matteoli, M, Parpura, V, Mothet, JP, Zorec, R: Astrocytes as secretory cells of the central nervous system: idiosyncrasies of vesicular secretion. EMBO J, 2016.

17. Wolburg, H, Neuhaus, J, Kniesel, U, Krauss, B, Schmid, E, Ocalan, M, Farrell, C, Risau, W: Modulation of tight junction structure in blood-brain barrier endothelial cells. Effects of tissue culture, second messengers and cocultured astrocytes. J Cell Sci, 107 ( Pt 5): 13471357, 1994.

18. Zorec, R, Araque, A, Carmignoto, G, Haydon, PG, Verkhratsky, A, Parpura, V: Astroglial excitability and gliotransmission: an appraisal of $\mathrm{Ca2}+$ as a signalling route. ASN Neuro, 4, 2012.

19. Liddelow, SA, Guttenplan, KA, Clarke, LE, Bennett, FC, Bohlen, CJ, Schirmer, L, Bennett, ML, Munch, AE, Chung, WS, Peterson, TC, Wilton, DK, Frouin, A, Napier, BA, Panicker, N, Kumar, M, Buckwalter, MS, Rowitch, DH, Dawson, VL, Dawson, TM, Stevens, B, Barres, BA: Neurotoxic reactive astrocytes are induced by activated microglia. Nature, 541: 481-487, 2017.

20. Thrane, AS, Rangroo Thrane, V, Nedergaard, M: Drowning stars: reassessing the role of astrocytes in brain edema. Trends Neurosci, 37: 620-628, 2014.

21. Zorec, R, Verkhratsky, A, Rodriguez, JJ, Parpura, V: Astrocytic vesicles and gliotransmitters: Slowness of vesicular release and synaptobrevin2-laden vesicle nanoarchitecture. Neuroscience, 323: 67-75, 2016.

22. Vardjan, N, Zorec, R: Excitable Astrocytes: $\mathrm{Ca}(2+)$ - and cAMP-Regulated Exocytosis. Neurochem

This article is protected by copyright. All rights reserved. 
Res, 40: 2414-2414, 2015.

23. Woese, $C R$, Kandler, $O$, Wheelis, ML: Towards a natural system of organisms: proposal for the domains Archaea, Bacteria, and Eucarya. Proc Natl Acad Sci U S A, 87: 4576-4579, 1990.

24. Ding, F, O'Donnell, J, Thrane, AS, Zeppenfeld, D, Kang, H, Xie, L, Wang, F, Nedergaard, M: $\mathbf{\alpha 1 -}$ Adrenergic receptors mediate coordinated $\mathrm{Ca2}+$ signaling of cortical astrocytes in awake, behaving mice. Cell Calcium, 54: 387-394, 2013.

25. Gribaldo, S, Brochier-Armanet, C: The origin and evolution of Archaea: a state of the art. Philos Trans R Soc Lond B Biol Sci, 361: 1007-1022, 2006.

26. Spang, A, Martijn, J, Saw, JH, Lind, AE, Guy, L, Ettema, TJ: Close encounters of the third domain: the emerging genomic view of archaeal diversity and evolution. Archaea, 2013: 202358, 2013.

27. Cavalier-Smith, $\mathrm{T}$ : The neomuran origin of archaebacteria, the negibacterial root of the universal tree and bacterial megaclassification. Int J Syst Evol Microbiol, 52: 7-76, 2002.

28. Brocks, JJ, Logan, GA, Buick, R, Summons, RE: Archean molecular fossils and the early rise of eukaryotes. Science, 285: 1033-1036, 1999.

29. Hartman, H, Fedorov, A: The origin of the eukaryotic cell: a genomic investigation. Proc NatI Acad Sci U S A, 99: 1420-1425, 2002.

30. Spang, A, Saw, JH, Jorgensen, SL, Zaremba-Niedzwiedzka, K, Martijn, J, Lind, AE, van Eijk, R, Schleper, C, Guy, L, Ettema, TJ: Complex archaea that bridge the gap between prokaryotes and eukaryotes. Nature, 521: 173-179, 2015.

31. Embley, TM, Martin, W: Eukaryotic evolution, changes and challenges. Nature, 440: 623-630, 2006.

32. Mukherjee, S, Ghosh, RN, Maxfield, FR: Endocytosis. Physiol Rev, 77: 759-803, 1997.

33. Takai, Y, Sasaki, T, Matozaki, T: Small GTP-binding proteins. Physiol Rev, 81: 153-208, 2001.

34. Hurley, JH: The ESCRT complexes. Crit Rev Biochem Mol Biol, 45: 463-487, 2010.

35. De Duve, C, Pressman, BC, Gianetto, R, Wattiaux, R, Appelmans, F: Tissue fractionation studies. 6. Intracellular distribution patterns of enzymes in rat-liver tissue. Biochem J, 60: 604-617, 1955.

36. de Duve, C: The lysosome turns fifty. Nat Cell Biol, 7: 847-849, 2005.

37. Settembre, C, Fraldi, A, Medina, DL, Ballabio, A: Signals from the lysosome: a control centre for cellular clearance and energy metabolism. Nat Rev Mol Cell Biol, 14: 283-296, 2013.

38. Essner, E, Novikoff, AB: Localization of acid phosphatase activity in hepatic lysosomes by means of electron microscopy. J Biophys Biochem Cytol, 9: 773-784, 1961.

39. Straus, W: Cytochemical Observations on the Relationship between Lysosomes and Phagosomes in Kidney and Liver by Combined Staining for Acid Phosphatase and

This article is protected by copyright. All rights reserved. 
Intravenously Injected Horseradish Peroxidase. J Cell Biol, 20: 497-507, 1964.

40. Verkhratsky, A: Physiology of neuronal-glial networking. Neurochem Int, 57: 332-343, 2010.

41. Verkhratsky, A, Krishtal, OA, Burnstock, G: Purinoceptors on neuroglia. Mol Neurobiol, 39: 190208, 2009.

42. Rusakov, DA, Zheng, $K$, Henneberger, C: Astrocytes as regulators of synaptic function: a quest for the Ca2+ master key. Neuroscientist, 17: 513-523, 2011.

43. Verkhratsky, A, Orkand, RK, Kettenmann, H: Glial calcium: homeostasis and signaling function. Physiol Rev, 78: 99-141, 1998.

44. Rose, CR, Verkhratsky, A: Principles of sodium homeostasis and sodium signalling in astroglia. Glia, 64: 1611-1627, 2016.

45. Kirischuk, S, Parpura, V, Verkhratsky, A: Sodium dynamics: another key to astroglial excitability? Trends Neurosci, 35: 497-506, 2012.

46. Vardjan, $N$, Kreft, $M$, Zorec, R: Dynamics of $\beta$-adrenergic/cAMP signaling and morphological changes in cultured astrocytes. Glia, 62: 566-579, 2014.

47. Held, H: Über die Neuroglia marginalis der menschlichen Grosshirnrinde. Monatschr $f$ Psychol u Neurol, 26 Rdg.-Heft: 360-416, 1909.

48. Nageotte, J: Phenomenes de secretion dans le protoplasma des cellules nevrogliques de la substance grise., Paris, 1910.

49. Kreft, M, Stenovec, M, Rupnik, M, Grilc, S, Krzan, M, Potokar, M, Pangrsic, T, Haydon, PG, Zorec, R: Properties of $\mathrm{Ca}(2+)$-dependent exocytosis in cultured astrocytes. Glia, 46: 437445, 2004.

50. Krzan, M, Stenovec, M, Kreft, M, Pangrsic, T, Grilc, S, Haydon, PG, Zorec, R: Calcium-dependent exocytosis of atrial natriuretic peptide from astrocytes. J Neurosci, 23: 1580-1583, 2003.

51. Vardjan, N, Kreft, M, Zorec, R: Regulated Exocytosis in Astrocytes is as Slow as the Metabolic Availability of Gliotransmitters: Focus on Glutamate and ATP. Adv Neurobiol, 11: 81-101, 2014.

52. Zorec, R, Horvat, A, Vardjan, N, Verkhratsky, A: Memory Formation Shaped by Astroglia. Front Integr Neurosci, 9: 56, 2015.

53. Vardjan, N, Gabrijel, M, Potokar, M, Svajger, U, Kreft, M, Jeras, M, de Pablo, Y, Faiz, M, Pekny,

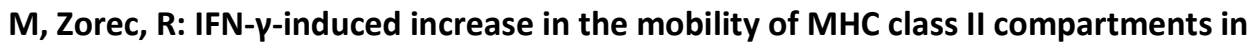
astrocytes depends on intermediate filaments. J Neuroinflammation, 9: 144, 2012.

54. Frohman, EM, Vayuvegula, B, Gupta, S, van den Noort, S: Norepinephrine inhibits gammainterferon-induced major histocompatibility class II (la) antigen expression on cultured astrocytes via beta-2-adrenergic signal transduction mechanisms. Proc Natl Acad Sci U S A, 85: 1292-1296, 1988.

55. Laureys, G, Clinckers, R, Gerlo, S, Spooren, A, Wilczak, N, Kooijman, R, Smolders, I, Michotte, Y, This article is protected by copyright. All rights reserved. 
De Keyser, J: Astrocytic beta(2)-adrenergic receptors: from physiology to pathology. Prog Neurobiol, 91: 189-199, 2010.

56. Plog, BA, Dashnaw, ML, Hitomi, E, Peng, W, Liao, Y, Lou, N, Deane, R, Nedergaard, M: Biomarkers of traumatic injury are transported from brain to blood via the glymphatic system. J Neurosci, 35: 518-526, 2015.

57. Xie, L, Kang, H, Xu, Q, Chen, MJ, Liao, Y, Thiyagarajan, M, O'Donnell, J, Christensen, DJ, Nicholson, C, lliff, JJ, Takano, T, Deane, R, Nedergaard, M: Sleep drives metabolite clearance from the adult brain. Science, 342: 373-377, 2013.

58. Wei, F, Zhang, C, Xue, R, Shan, L, Gong, S, Wang, G, Tao, J, Xu, G, Zhang, G, Wang, L: The pathway of subarachnoid CSF moving into the spinal parenchyma and the role of astrocytic aquaporin-4 in this process. Life Sci, 2017.

59. Vindedal, GF, Thoren, AE, Jensen, V, Klungland, A, Zhang, Y, Holtzman, MJ, Ottersen, OP, Nagelhus, EA: Removal of aquaporin-4 from glial and ependymal membranes causes brain water accumulation. Mol Cell Neurosci, 77: 47-52, 2016.

60. Alvarez, JI, Katayama, T, Prat, A: Glial influence on the blood brain barrier. Glia, 61: 1939-1958, 2013.

61. Pangrsic, T, Potokar, M, Haydon, PG, Zorec, R, Kreft, M: Astrocyte swelling leads to membrane unfolding, not membrane insertion. J Neurochem, 99: 514-523, 2006.

62. Vardjan, N, Horvat, A, Anderson, JE, Yu, D, Croom, D, Zeng, X, Luznik, Z, Kreft, M, Teng, YD, Kirov, SA, Zorec, R: Adrenergic activation attenuates astrocyte swelling induced by hypotonicity and neurotrauma. Glia, 64: 1034-1049, 2016.

63. Ponath, G, Ramanan, S, Mubarak, M, Housley, W, Lee, S, Sahinkaya, FR, Vortmeyer, A, Raine, CS, Pitt, D: Myelin phagocytosis by astrocytes after myelin damage promotes lesion pathology. Brain, 140: 399-413, 2017.

64. Mills, EA, Davis, CH, Bushong, EA, Boassa, D, Kim, KY, Ellisman, MH, Marsh-Armstrong, N: Astrocytes phagocytose focal dystrophies from shortening myelin segments in the optic nerve of Xenopus laevis at metamorphosis. Proc Natl Acad Sci U S A, 112: 10509-10514, 2015.

65. Tasdemir-Yilmaz, OE, Freeman, MR: Astrocytes engage unique molecular programs to engulf pruned neuronal debris from distinct subsets of neurons. Genes Dev, 28: 20-33, 2014.

66. Hakim, Y, Yaniv, SP, Schuldiner, O: Astrocytes play a key role in Drosophila mushroom body axon pruning. PLoS One, 9: e86178, 2014.

67. Shahzad, R, Jones, MR, Viles, JH, Jones, CE: Endocytosis of the tachykinin neuropeptide, neurokinin B, in astrocytes and its role in cellular copper uptake. J Inorg Biochem, 162: 319325, 2016.

68. Bergami, M, Santi, S, Formaggio, E, Cagnoli, C, Verderio, C, Blum, R, Berninger, B, Matteoli, M, Canossa, M: Uptake and recycling of pro-BDNF for transmitter-induced secretion by cortical

This article is protected by copyright. All rights reserved. 
astrocytes. J Cell Biol, 183: 213-221, 2008.

69. Donato, R, Sorci, G, Riuzzi, F, Arcuri, C, Bianchi, R, Brozzi, F, Tubaro, C, Giambanco, I: S100B's double life: intracellular regulator and extracellular signal. Biochim Biophys Acta, 1793: 1008-1022, 2009.

70. Lasic, E, Galland, F, Vardjan, N, Sribar, J, Krizaj, I, Leite, MC, Zorec, R, Stenovec, M: Timedependent uptake and trafficking of vesicles capturing extracellular $\mathrm{S100B}$ in cultured rat astrocytes. J Neurochem, 139: 309-323, 2016.

71. Potokar, M, Stenovec, M, Gabrijel, M, Li, L, Kreft, M, Grilc, S, Pekny, M, Zorec, R: Intermediate filaments attenuate stimulation-dependent mobility of endosomes/lysosomes in astrocytes. Glia, 58: 1208-1219, 2010.

72. Parpura, V, Zorec, R: Gliotransmission: Exocytotic release from astrocytes. Brain Res Rev, 63: 83-92, 2010.

73. Kreft, M, Krizaj, D, Grilc, S, Zorec, R: Properties of exocytotic response in vertebrate photoreceptors. J Neurophysiol, 90: 218-225, 2003.

74. Parpura, V, Basarsky, TA, Liu, F, Jeftinija, K, Jeftinija, S, Haydon, PG: Glutamate-mediated astrocyte-neuron signalling. Nature, 369: 744-747, 1994.

75. Neher, E, Marty, A: Discrete changes of cell membrane capacitance observed under conditions of enhanced secretion in bovine adrenal chromaffin cells. Proc Natl Acad Sci U S A, 79: 6712-6716, 1982.

76. Kreft, M, Zorec, R: Cell-attached measurements of attofarad capacitance steps in rat melanotrophs. Pflugers Arch, 434: 212-214, 1997.

77. Rituper, B, Gucek, A, Jorgacevski, J, Flasker, A, Kreft, M, Zorec, R: High-resolution membrane capacitance measurements for the study of exocytosis and endocytosis. Nat Protoc, 8: 1169-1183, 2013.

78. Jorgacevski, J, Potokar, M, Kreft, M, Gucek, A, Mothet, JP, Zorec, R: Astrocytic Vesicle-based Exocytosis in Cultures and Acutely Isolated Hippocampal Rodent Slices. J Neurosci Res, doi: 10.1002/jnr.24051, 2017.

79. Bergersen, LH, Morland, C, Ormel, L, Rinholm, JE, Larsson, M, Wold, JF, Roe, AT, Stranna, A, Santello, M, Bouvier, D, Ottersen, OP, Volterra, A, Gundersen, V: Immunogold detection of L-glutamate and $\mathrm{D}$-serine in small synaptic-like microvesicles in adult hippocampal astrocytes. Cereb Cortex, 22: 1690-1697, 2012.

80. Jourdain, P, Bergersen, LH, Bhaukaurally, K, Bezzi, P, Santello, M, Domercq, M, Matute, C, Tonello, F, Gundersen, V, Volterra, A: Glutamate exocytosis from astrocytes controls synaptic strength. Nat Neurosci, 10: 331-339, 2007.

81. Bowser, DN, Khakh, BS: Two forms of single-vesicle astrocyte exocytosis imaged with total internal reflection fluorescence microscopy. Proc Natl Acad Sci U S A, 104: 4212-4217, 2007.

This article is protected by copyright. All rights reserved. 
82. Malarkey, EB, Parpura, V: Temporal characteristics of vesicular fusion in astrocytes: examination of synaptobrevin 2-laden vesicles at single vesicle resolution. J Physiol, 589: 4271-4300, 2011.

83. Gucek, A, Jorgacevski, J, Singh, P, Geisler, C, Lisjak, M, Vardjan, N, Kreft, M, Egner, A, Zorec, R: Dominant negative SNARE peptides stabilize the fusion pore in a narrow, releaseunproductive state. Cell Mol Life Sci, 73: 3719-3731, 2016.

84. Pangrsic, T: Exocytotic release of ATP from cultured astrocytes. J Biol Chem, 282: 28749-28758, 2007.

85. Jorgacevski, J, Potokar, M, Grilc, S, Kreft, M, Liu, W, Barclay, JW, Buckers, J, Medda, R, Hell, SW, Parpura, V, Burgoyne, RD, Zorec, R: Munc18-1 tuning of vesicle merger and fusion pore properties. J Neurosci, 31: 9055-9066, 2011.

86. Flasker, A, Jorgacevski, J, Calejo, Al, Kreft, M, Zorec, R: Vesicle size determines unitary exocytic properties and their sensitivity to sphingosine. Mol Cell Endocrinol, 376: 136-147, 2013.

87. Jorgacevski, J, Fosnaric, M, Vardjan, N, Stenovec, M, Potokar, M, Kreft, M, Kralj-Iglic, V, Iglic, A, Zorec, R: Fusion pore stability of peptidergic vesicles. Mol Membr Biol, 27: 65-80, 2010.

88. Potokar, M, Kreft, M, Pangrsic, T, Zorec, R: Vesicle mobility studied in cultured astrocytes. Biochem Biophys Res Commun, 329: 678-683, 2005.

89. Burke, N, Han, W, Li, D, Takimoto, K, Watkins, S, Levitan, E: Neuronal peptide release is limited by secretory granule mobility. Neuron, 19: 1095-1102, 1997.

90. Tvaruskó, W, Bentele, M, Misteli, T, Rudolf, R, Kaether, C, Spector, D, Gerdes, H, Eils, R: Timeresolved analysis and visualization of dynamic processes in living cells. Proc Natl Acad Sci U $S A$, 96: 7950-7955, 1999.

91. Duncan, R, Greaves, J, Wiegand, U, Matskevich, I, Bodammer, G, Apps, D, Shipston, M, Chow, R: Functional and spatial segregation of secretory vesicle pools according to vesicle age. Nature, 422: 176-180, 2003.

92. Vardjan, N, Verkhratsky, A, Zorec, R: Pathologic potential of astrocytic vesicle traffic: new targets to treat neurologic diseases? Cell transplantation, 24: 599-612, 2015.

93. Potokar, M, Vardjan, N, Stenovec, M, Gabrijel, M, Trkov, S, Jorgacevski, J, Kreft, M, Zorec, R: Astrocytic vesicle mobility in health and disease. International journal of molecular sciences, 14: 11238-11258, 2013.

94. Stenovec, M, Kreft, M, Grilc, S, Potokar, M, Kreft, ME, Pangrsic, T, Zorec, R: $\mathrm{Ca}^{2+}$-dependent mobility of vesicles capturing anti-VGLUT1 antibodies. Experimental cell research, 313: 3809-3818, 2007.

95. Potokar, M, Stenovec, M, Kreft, M, Kreft, ME, Zorec, R: Stimulation inhibits the mobility of recycling peptidergic vesicles in astrocytes. Glia, 56: 135-144, 2008.

96. Potokar, M, Kreft, M, Lee, SY, Takano, H, Haydon, PG, Zorec, R: Trafficking of astrocytic vesicles in hippocampal slices. Biochem Biophys Res Commun, 390: 1192-1196, 2009.

This article is protected by copyright. All rights reserved. 
97. Burda, JE, Bernstein, AM, Sofroniew, MV: Astrocyte roles in traumatic brain injury. Exp Neurol, 275 Pt 3: 305-315, 2016.

98. Burda, JE, Sofroniew, MV: Reactive gliosis and the multicellular response to CNS damage and disease. Neuron, 81: 229-248, 2014.

99. Giaume, C, Kirchhoff, F, Matute, C, Reichenbach, A, Verkhratsky, A: Glia: the fulcrum of brain diseases. Cell Death Differ, 14: 1324-1335, 2007.

100. Pekny, M, Pekna, M: Astrocyte reactivity and reactive astrogliosis: costs and benefits. Physiol Rev, 94: 1077-1098, 2014.

101. Verkhratsky, A, Parpura, V: Astrogliopathology in neurological, neurodevelopmental and psychiatric disorders. Neurobiol Dis, 85: 254-261, 2015.

102. Zorec, R, Vardjan, N, Verkhratsky, A: Locus coeruleus noradrenergic neurons and astroglia in health and disease. In: Noradrenergic Signaling and Astroglia. edited by VARDJAN, N., ZOREC, R., New York, Elsevier, 2017, pp 1-10.

103. Pekny, M, Pekna, M: Reactive gliosis in the pathogenesis of CNS diseases. Biochim Biophys Acta, 1862: 483-491, 2016.

104. Olabarria, M, Noristani, HN, Verkhratsky, A, Rodríguez, JJ: Concomitant astroglial atrophy and astrogliosis in a triple transgenic animal model of Alzheimer's disease. Glia, 58: 831-838, 2010.

105. Jones, VC, Atkinson-Dell, R, Verkhratsky, A, Mohamet, L: Aberrant iPSC-derived human astrocytes in Alzheimer's disease. Cell Death Dis, 8: e2696, 2017.

106. Stenovec, M, Lasic, E, Bozic, M, Bobnar, ST, Stout, RF, Jr., Grubisic, V, Parpura, V, Zorec, R: Ketamine Inhibits ATP-Evoked Exocytotic Release of Brain-Derived Neurotrophic Factor from Vesicles in Cultured Rat Astrocytes. Mol Neurobiol, 53: 6882-6896, 2016.

107. Chakraborti, S, Natarajan, K, Curiel, J, Janke, C, Liu, J: The emerging role of the tubulin code: From the tubulin molecule to neuronal function and disease. Cytoskeleton (Hoboken), 73: 521-550, 2016.

108. Potokar, M, Kreft, M, Li, L, Daniel Andersson, J, Pangrsic, T, Chowdhury, HH, Pekny, M, Zorec, R: Cytoskeleton and vesicle mobility in astrocytes. Traffic, 8: 12-20, 2007.

109. Moody, LR, Barrett-Wilt, GA, Sussman, MR, Messing, A: Glial Fibrillary Acidic Protein Exhibits Altered Turnover Kinetics in a Mouse Model of Alexander Disease. J Biol Chem, 2017.

110. Delepine, C, Meziane, H, Nectoux, J, Opitz, M, Smith, AB, Ballatore, C, Saillour, Y, BennaceurGriscelli, A, Chang, $Q$, Williams, EC, Dahan, $M$, Duboin, A, Billuart, $P$, Herault, $Y$, Bienvenu, $T$ : Altered microtubule dynamics and vesicular transport in mouse and human MeCP2deficient astrocytes. Hum Mol Genet, 25: 146-157, 2016.

111. Stenovec, M, Trkov, S, Lasič, E, Terzieva, S, Kreft, M, Rodríguez Arellano, JJ, Parpura, V, Verkhratsky, A, Zorec, R: Expression of familial Alzheimer disease presenilin 1 gene attenuates vesicle traffic and reduces peptide secretion in cultured astrocytes devoid of

This article is protected by copyright. All rights reserved. 
pathologic tissue environment. Glia, 64: 317-329, 2016.

112. Hong, Y, Zhao, T, Li, XJ, Li, S: Mutant Huntingtin Impairs BDNF Release from Astrocytes by Disrupting Conversion of Rab3a-GTP into Rab3a-GDP. J Neurosci, 36: 8790-8801, 2016.

113. Stenovec, M, Milosevic, M, Petrusic, V, Potokar, M, Stevic, Z, Prebil, M, Kreft, M, Trkov, S, Andjus, PR, Zorec, R: Amyotrophic lateral sclerosis immunoglobulins $\mathbf{G}$ enhance the mobility of Lysotracker-labelled vesicles in cultured rat astrocytes. Acta Physiol (Oxf), 203: 457-471, 2011.

114. Milosevic, M, Stenovec, M, Kreft, M, Petrusic, V, Stevic, Z, Trkov, S, Andjus, PR, Zorec, R: Immunoglobulins $\mathrm{G}$ from patients with sporadic amyotrophic lateral sclerosis affects cytosolic Ca2+ homeostasis in cultured rat astrocytes. Cell Calcium, 54: 17-25, 2013.

115. Potokar, M, Lacovich, V, Chowdhury, HH, Kreft, M, Zorec, R: Rab4 and Rab5 GTPase are required for directional mobility of endocytic vesicles in astrocytes. Glia, 60: 594-604, 2012.

116. Potokar, M, Jorgačevski, J, Lacovich, V, Kreft, M, Vardjan, N, Bianchi, V, D’Adamo, P, Zorec, R: Impaired $\alpha$ GDI function in the X-linked intellectual disability: the impact on astroglia vesicle dynamics. Mol Neurobiol, in press, 2016.

117. Potokar, M, Korva, M, Jorgacevski, J, Avsic-Zupanc, T, Zorec, R: Tick-borne encephalitis virus infects rat astrocytes but does not affect their viability. PLoS One, 9: e86219, 2014.

118. Marignier, R, De Seze, J, Vukusic, S, Durand-Dubief, F, Zephir, H, Vermersch, P, Cabre, P, Cavillon, G, Honnorat, J, Confavreux, C: NMO-IgG and Devic's neuromyelitis optica: a French experience. Mult Scler, 14: 440-445, 2008.

119. Lennon, VA, Wingerchuk, DM, Kryzer, TJ, Pittock, SJ, Lucchinetti, CF, Fujihara, K, Nakashima, I, Weinshenker, BG: A serum autoantibody marker of neuromyelitis optica: distinction from multiple sclerosis. Lancet, 364: 2106-2112, 2004.

120. Potokar, M, Stenovec, M, Jorgacevski, J, Holen, T, Kreft, M, Ottersen, OP, Zorec, R: Regulation of AQP4 surface expression via vesicle mobility in astrocytes. Glia, 61: 917-928, 2013.

121. Potokar, M, Jorgacevski, J, Zorec, R: Astrocyte Aquaporin Dynamics in Health and Disease. Int J Mol Sci, 17, 2016.

122. Trkov, S, Stenovec, M, Kreft, M, Potokar, M, Parpura, V, Davletov, B, Zorec, R: Fingolimod--a sphingosine-like molecule inhibits vesicle mobility and secretion in astrocytes. Glia, 60: 1406-1416, 2012.

123. Lasic, E, Rituper, B, Jorgacevski, J, Kreft, M, Stenovec, M, Zorec, R: Subanesthetic doses of ketamine stabilize the fusion pore in a narrow flickering state in astrocytes. $J$ Neurochem, 138: 909-917, 2016.

124. Macauley, SL, Pekny, M, Sands, MS: The role of attenuated astrocyte activation in infantile neuronal ceroid lipofuscinosis. J Neurosci, 31: 15575-15585, 2011.

125. Platt, FM, Boland, B, van der Spoel, AC: The cell biology of disease: lysosomal storage disorders: the cellular impact of lysosomal dysfunction. J Cell Biol, 199: 723-734, 2012.

This article is protected by copyright. All rights reserved. 
126. Boustany, RM: Lysosomal storage diseases--the horizon expands. Nat Rev Neurol, 9: 583-598, 2013.

127. Rama Rao, KV, Kielian, T: Astrocytes and lysosomal storage diseases. Neuroscience, 323: 195206, 2016.

128. Prada, CE, Grabowski, GA: Neuronopathic lysosomal storage diseases: clinical and pathologic findings. Dev Disabil Res Rev, 17: 226-246, 2013.

129. Hechtman, P, Kaplan, F: Tay-Sachs disease screening and diagnosis: evolving technologies. DNA Cell Biol, 12: 651-665, 1993.

130. Itoh, H, Tanaka, J, Morihana, Y, Tamaki, T: The fine structure of cytoplasmic inclusions in brain and other visceral organs in Sandhoff disease. Brain Dev, 6: 467-474, 1984.

131. Brady, RO, Kanfer, JN, Mock, MB, Fredrickson, DS: The metabolism of sphingomyelin. II. Evidence of an enzymatic deficiency in Niemann-Pick diseae. Proc Natl Acad Sci U S A, 55: 366-369, 1966.

132. Jmoudiak, $M$, Futerman, AH: Gaucher disease: pathological mechanisms and modern management. Br J Haematol, 129: 178-188, 2005.

133. Burkovetskaya, M, Karpuk, N, Xiong, J, Bosch, M, Boska, MD, Takeuchi, H, Suzumura, A, Kielian, T: Evidence for aberrant astrocyte hemichannel activity in Juvenile Neuronal Ceroid Lipofuscinosis (JNCL). PLoS One, 9: e95023, 2014.

134. Di Malta, C, Fryer, JD, Settembre, C, Ballabio, A: Autophagy in astrocytes: a novel culprit in lysosomal storage disorders. Autophagy, 8: 1871-1872, 2012.

135. Mlakar, J, Korva, M, Tul, N, Popovic, M, Poljsak-Prijatelj, M, Mraz, J, Kolenc, M, Resman Rus, K, Vesnaver Vipotnik, T, Fabjan Vodusek, V, Vizjak, A, Pizem, J, Petrovec, M, Avsic Zupanc, T: Zika Virus Associated with Microcephaly. N Engl J Med, 374: 951-958, 2016.

136. Gritsun, T, Lashkevich, V, Gould, E: Tick-borne encephalitis. Antiviral Res, 57: 129-146, 2003.

137. Chu, J, Ng, M: Infectious entry of West Nile virus occurs through a clathrin-mediated endocytic pathway. J Virol, 78: 10543-10555, 2004.

138. Mandl, C: Steps of the tick-borne encephalitis virus replication cycle that affect neuropathogenesis. Virus Res, 111: 161-174, 2005.

139. Růzek, D, Bell-Sakyi, L, Kopecký, J, Grubhoffer, L: Growth of tick-borne encephalitis virus (European subtype) in cell lines from vector and non-vector ticks. Virus Res, 137: 142-146, 2008.

140. Chauhan, A, Tikoo, A, Patel, J, Abdullah, AM: HIV-1 endocytosis in astrocytes: a kiss of death or survival of the fittest? Neurosci Res, 88: 16-22, 2014.

141. Bernacki, J, Dobrowolska, A, Nierwińska, K, Małecki, A: Physiology and pharmacological role of the blood-brain barrier. Pharmacol Rep, 60: 600-622, 2008.

142. Carmignoto, G, Gómez-Gonzalo, M: The contribution of astrocyte signalling to neurovascular This article is protected by copyright. All rights reserved. 
coupling. Brain Res Rev, 63: 138-148, 2010.

143. Attwell, D, Buchan, AM, Charpak, S, Lauritzen, M, Macvicar, BA, Newman, EA: Glial and neuronal control of brain blood flow. Nature, 468: 232-243, 2010.

144. Vander Heiden, MG, Cantley, LC, Thompson, CB: Understanding the Warburg effect: the metabolic requirements of cell proliferation. Science, 324: 1029-1033, 2009.

145. Tech, K, Gershon, TR: Energy metabolism in neurodevelopment and medulloblastoma. TransI Pediatr, 4: 12-19, 2015.

146. Goyal, MS, Hawrylycz, M, Miller, JA, Snyder, AZ, Raichle, ME: Aerobic glycolysis in the human brain is associated with development and neotenous gene expression. Cell Metab, 19: 4957, 2014.

147. Meertens, L, Labeau, A, Dejarnac, O, Cipriani, S, Sinigaglia, L, Bonnet-Madin, L, Le Charpentier, T, Hafirassou, ML, Zamborlini, A, Cao-Lormeau, VM, Coulpier, M, Misse, D, Jouvenet, N, Tabibiazar, R, Gressens, P, Schwartz, O, Amara, A: AxI Mediates ZIKA Virus Entry in Human Glial Cells and Modulates Innate Immune Responses. Cell Rep, 18: 324-333, 2017.

148. Lemke, G, Rothlin, CV: Immunobiology of the TAM receptors. Nat Rev Immunol, 8: 327-336, 2008.

149. Foote, SL, Bloom, FE, Aston-Jones, G: Nucleus locus ceruleus: new evidence of anatomical and physiological specificity. Physiol Rev, 63: 844-914, 1983.

150. Prebil, M, Vardjan, N, Jensen, J, Zorec, R, Kreft, M: Dynamic monitoring of cytosolic glucose in single astrocytes. Glia, 59: 903-913, 2011.

151. Dienel, GA, Cruz, NF: Aerobic glycolysis during brain activation: Adrenergic regulation and influence of norepinephrine on astrocytic metabolism. J Neurochem, 2016.

152. Tang, F, Lane, S, Korsak, A, Paton, JF, Gourine, AV, Kasparov, S, Teschemacher, AG: Lactatemediated glia-neuronal signalling in the mammalian brain. Nat Commun, 5: 3284, 2014.

153. Oddo, S, Caccamo, A, Shepherd, JD, Murphy, MP, Golde, TE, Kayed, R, Metherate, R, Mattson, MP, Akbari, Y, LaFerla, FM: Triple-transgenic model of Alzheimer's disease with plaques and tangles: intracellular Abeta and synaptic dysfunction. Neuron, 39: 409-421, 2003.

154. Son, SM, Cha, MY, Choi, H, Kang, S, Lee, MS, Park, SA, Mook-Jung, I: Insulin-degrading enzyme secretion from astrocytes is mediated by an autophagy-based unconventional secretory pathway in Alzheimer disease. Autophagy, 12: 784-800, 2016.

155. Vekrellis, K, Ye, Z, Qiu, WQ, Walsh, D, Hartley, D, Chesneau, V, Rosner, MR, Selkoe, DJ: Neurons regulate extracellular levels of amyloid beta-protein via proteolysis by insulindegrading enzyme. J Neurosci, 20: 1657-1665, 2000.

156. Son, SM, Kang, S, Choi, H, Mook-Jung, I: Statins induce insulin-degrading enzyme secretion from astrocytes via an autophagy-based unconventional secretory pathway. Mol Neurodegener, 10: 56, 2015.

This article is protected by copyright. All rights reserved. 
157. Sreetama, SC, Takano, T, Nedergaard, M, Simon, SM, Jaiswal, JK: Injured astrocytes are repaired by Synaptotagmin XI-regulated lysosome exocytosis. Cell Death Differ, 23: 596607, 2016.

158. Verkhratsky, A, Parpura, V, Pekna, M, Pekny, M, Sofroniew, M: Glia in the pathogenesis of neurodegenerative diseases. Biochem Soc Trans, 42: 1291-1301, 2014.

159. Soos, JM, Morrow, J, Ashley, TA, Szente, BE, Bikoff, EK, Zamvil, SS: Astrocytes express elements of the class II endocytic pathway and process central nervous system autoantigen for presentation to encephalitogenic T cells. J Immunol, 161: 5959-5966, 1998.

160. Wubbolts, R, Fernandez-Borja, M, Jordens, I, Reits, E, Dusseljee, S, Echeverri, C, Vallee, RB, Neefjes, J: Opposing motor activities of dynein and kinesin determine retention and transport of MHC class II-containing compartments. J Cell Sci, 112 ( Pt 6): 785-795, 1999.

161. Vyas, JM, Kim, YM, Artavanis-Tsakonas, K, Love, JC, Van der Veen, AG, Ploegh, HL: Tubulation of class II MHC compartments is microtubule dependent and involves multiple endolysosomal membrane proteins in primary dendritic cells. J Immunol, 178: 7199-7210, 2007.

162. Barois, N, Forquet, F, Davoust, J: Actin microfilaments control the MHC class II antigen presentation pathway in B cells. J Cell Sci, 111 ( Pt 13): 1791-1800, 1998.

163. Vascotto, F, Lankar, D, Faure-André, G, Vargas, P, Diaz, J, Le Roux, D, Yuseff, MI, Sibarita, JB, Boes, M, Raposo, G, Mougneau, E, Glaichenhaus, N, Bonnerot, C, Manoury, B, LennonDuménil, AM: The actin-based motor protein myosin II regulates MHC class II trafficking and BCR-driven antigen presentation. J Cell Biol, 176: 1007-1019, 2007.

164. Sheen, VL, Ganesh, VS, Topcu, M, Sebire, G, Bodell, A, Hill, RS, Grant, PE, Shugart, YY, Imitola, J, Khoury, SJ, Guerrini, R, Walsh, CA: Mutations in ARFGEF2 implicate vesicle trafficking in neural progenitor proliferation and migration in the human cerebral cortex. Nat Genet, 36: 69-76, 2004.

165. Barber, M, Arai, Y, Morishita, Y, Vigier, L, Causeret, F, Borello, U, Ledonne, F, Coppola, E, Contremoulins, V, Pfrieger, FW, Tissir, F, Govindan, S, Jabaudon, D, Proux-Gillardeaux, V, Galli, T, Pierani, A: Migration Speed of Cajal-Retzius Cells Modulated by Vesicular Trafficking Controls the Size of Higher-Order Cortical Areas. Curr Biol, 25: 2466-2478, 2015.

166. Luckasson, R, Reeve, A: Naming, defining, and classifying in mental retardation. Ment Retard, 39: 47-52, 2001.

167. Turner, G: Finding genes on the $X$ chromosome by which homo may have become sapiens. Am J Hum Genet, 58: 1109-1110, 1996.

168. D'Adamo, P, Menegon, A, Lo Nigro, C, Grasso, M, Gulisano, M, Tamanini, F, Bienvenu, T, Gedeon, AK, Oostra, B, Wu, SK, Tandon, A, Valtorta, F, Balch, WE, Chelly, J, Toniolo, D: Mutations in GDI1 are responsible for X-linked non-specific mental retardation. Nat Genet, 19: 134-139, 1998.

169. Stenmark, H: Rab GTPases as coordinators of vesicle traffic. Nat Rev Mol Cell Biol, 10: 513-525,

This article is protected by copyright. All rights reserved. 
2009.

170. D'Adamo, P, Welzl, H, Papadimitriou, S, Raffaele di Barletta, M, Tiveron, C, Tatangelo, L, Pozzi, L, Chapman, PF, Knevett, SG, Ramsay, MF, Valtorta, F, Leoni, C, Menegon, A, Wolfer, DP, Lipp, HP, Toniolo, D: Deletion of the mental retardation gene Gdi1 impairs associative memory and alters social behavior in mice. Hum Mol Genet, 11: 2567-2580, 2002.

171. Bianchi, V, Farisello, $P$, Baldelli, $P$, Meskenaite, V, Milanese, $M$, Vecellio, M, Muhlemann, $S$, Lipp, HP, Bonanno, G, Benfenati, F, Toniolo, D, D'Adamo, P: Cognitive impairment in Gdi1deficient mice is associated with altered synaptic vesicle pools and short-term synaptic plasticity, and can be corrected by appropriate learning training. Hum Mol Genet, 18: 105117, 2009.

172. Lioy, DT, Garg, SK, Monaghan, CE, Raber, J, Foust, KD, Kaspar, BK, Hirrlinger, PG, Kirchhoff, F, Bissonnette, JM, Ballas, N, Mandel, G: A role for glia in the progression of Rett's syndrome. Nature, 475: 497-500, 2011.

173. Chun, J, Brinkmann, V: A mechanistically novel, first oral therapy for multiple sclerosis: the development of fingolimod (FTY720, Gilenya). Discov Med, 12: 213-228, 2011.

174. Brinkmann, V, Billich, A, Baumruker, T, Heining, P, Schmouder, R, Francis, G, Aradhye, S, Burtin, P: Fingolimod (FTY720): discovery and development of an oral drug to treat multiple sclerosis. Nat Rev Drug Discov, 9: 883-897, 2010.

175. Murphy, S, Pearce, B, Jeremy, J, Dandona, P: Astrocytes as eicosanoid-producing cells. Glia, 1: 241-245, 1988.

176. Kreft, M, Jorgacevski, J, Vardjan, N, Zorec, R: Unproductive exocytosis. J Neurochem, 137: 880889, 2016.

177. Chou, JY, Jun, HS, Mansfield, BC: Type I glycogen storage diseases: disorders of the glucose-6phosphatase/glucose-6-phosphate transporter complexes. J Inherit Metab Dis, 38: 511-519, 2013.

This article is protected by copyright. All rights reserved. 
Table 1 Neurological diseases associated with primary and secondary vesicle network defects

\begin{tabular}{|c|c|c|c|c|}
\hline & \multicolumn{2}{|c|}{$\begin{array}{l}\text { Astroglial Vesicle } \\
\text { Network Defect }\end{array}$} & \multirow[b]{2}{*}{ Mechanism/Comment } & \multirow[b]{2}{*}{ Reference } \\
\hline $\begin{array}{l}\text { Diseases and } \\
\text { neuropathological states }\end{array}$ & Primary & Secondary & & \\
\hline $\begin{array}{c}\text { Tay Sachs disease, a } \\
\text { member of the lysosomal } \\
\text { storage diseases }\end{array}$ & & $\mathrm{X}$ & Hexosaminidase A deficiency & 129 \\
\hline $\begin{array}{c}\text { Sandhoff disease, a } \\
\text { member of the lysosomal } \\
\text { storage diseases }\end{array}$ & & $x$ & $\begin{array}{l}\text { Hexosaminidase } A \text { and } B \\
\text { deficiency }\end{array}$ & 127 \\
\hline $\begin{array}{c}\text { Nieman-Pick's Type A } \\
\text { disease, a lipid storage } \\
\text { disorder }\end{array}$ & & $\mathrm{x}$ & Sphyngomyelinase deficiency & 131 \\
\hline Alexander's disease & $\mathrm{X}$ & & Cytoskeletal defect & 109 \\
\hline $\begin{array}{c}\text { Devic's disease } \\
\text { (Neuromyelitis optica) }\end{array}$ & $\mathrm{X}$ ? & & $\begin{array}{l}\text { Autoantibodies against AQP4, } \\
\text { affecting AQP4 vesicle dynamics }\end{array}$ & $118-120$ \\
\hline Alzheimer's Disease & $\mathrm{X}$ & & General vesicle traffic defect & 111 \\
\hline Intellectual Deficiency & $\mathrm{X}$ & & General vesicle traffic defect & 116 \\
\hline Rett's disease & $\mathrm{x}$ & & $\begin{array}{c}\text { General vesicle traffic } \\
\text { defect/cytoskeletal defect }\end{array}$ & 110 \\
\hline $\begin{array}{c}\text { Glycogen Storage } \\
\text { Disease }\end{array}$ & & $\mathrm{x}$ & $\begin{array}{c}\text { Glucose-6- phosphatase } \\
\text { deficiency }\end{array}$ & 177 . \\
\hline $\begin{array}{c}\text { Neuroinfection by } \\
\text { viruses (Tick-borne } \\
\text { encephalitis virus - TBEV) }\end{array}$ & $X ?$ & & $\begin{array}{l}\text { Affecting endocytosis and } \\
\text { endolysosomal traffic dynamics }\end{array}$ & 117 \\
\hline $\begin{array}{l}\text { Amyotrophic lateral } \\
\text { sclerosis (ALS) }\end{array}$ & $X ?$ & & Signalling and vesicle traffic defect & 113,114 \\
\hline Huntington's Disease & $\mathrm{x}$ & & $\begin{array}{l}\text { Mutated huntingtin affects vesicle } \\
\text { traffic }\end{array}$ & 112 \\
\hline $\begin{array}{l}\text { Ketamine treated } \\
\text { psychiatric disease }\end{array}$ & $\mathrm{x}$ & & $\begin{array}{l}\text { Affecting vesicle merger with the } \\
\text { plasma membrane/signalling }\end{array}$ & 106,123 \\
\hline $\begin{array}{l}\text { Fingolimod (FTY 720) } \\
\text { treated multiple sclerosis }\end{array}$ & $\mathrm{X}$ & & Affecting vesicle dynamics & 122 \\
\hline
\end{tabular}

This article is protected by copyright. All rights reserved. 


\begin{tabular}{|c|c|c|c|c|}
\hline Reactive gliosis & $x$ & & $\begin{array}{l}\text { Overexpression of intermediate } \\
\text { filaments affects vesicle dynamics }\end{array}$ & 108 \\
\hline $\begin{array}{l}\text { Microcephaly, } \\
\text { lissencephay }\end{array}$ & $x$ & & $\begin{array}{l}\text { Tubulin cytoskeleton alterations } \\
\text { in radial glia leading to abnormal } \\
\text { cell division and migration }\end{array}$ & 107 \\
\hline Gaucher disease & & $x$ & $\begin{array}{l}\text { deficient acid-beta-glucosidase, } \\
\text { leading to accumulation of } \\
\text { glucosylceramide }\end{array}$ & 132 \\
\hline $\begin{array}{l}\text { Krabbe disease, a form of } \\
\text { leukodystrophy }\end{array}$ & & $x$ & $\begin{array}{c}\text { deficiency of } \beta \text { - } \\
\text { galactocerebrosidase leads to } \\
\text { build-up of unmetabolized lipids } \\
\text { affecting the growth of the myelin } \\
\text { sheath }\end{array}$ & 127 \\
\hline $\begin{array}{c}\text { Infantile neuronal ceroid } \\
\text { lipofuscinosis (INCL), } \\
\text { neurodegenerative } \\
\text { disease }\end{array}$ & & $x$ & $\begin{array}{c}\text { Deficiency of palmitoyl protein } \\
\text { thioesterase } 1 \text {, a lysosomal } \\
\text { enzyme }\end{array}$ & 124 \\
\hline $\begin{array}{l}\text { Batten disease, neuronal } \\
\text { ceroid lipofuscinoses, a } \\
\text { form of lysosomal } \\
\text { storage diseases }\end{array}$ & & $x$ & $\begin{array}{l}\text { Lipofuscin materials build up in } \\
\text { neuronal cells and many organs }\end{array}$ & 133 \\
\hline
\end{tabular}

\section{Figure legends}

Figure 1. The vesicular-lysosome network.

Intracellular secretory organelles (synaptic-like vesicles, dense-core vesicles and primary lysosomes) originate from the endoplamic reticulum and Golgi complex. Primary lysosomes fuse with endosomes, phagosomes and autopahgosomes and convert to secondary lysosomes which undergo exocytosis thus expelling products of degradation. The multivesicular bosies contain exosomes that may carry various signalling factors.

Figure 2. Time-dependence of the number of endosomes and lysosomes associated with DiD-TBEV particles in astrocytes.

(Ai,ii). An astrocyte with DiD-labelled TBEV vesicles (TBEV) incubated at 37 ㅇ for $4 \mathrm{~h}$ and $18 \mathrm{~h}$ and with labelled early endosomes (EEA1) Overlays represents overlapped TBEV and EEA1 fluorescent signals, indicating the association between TBEV and endosomes. Bars: $5 \mu \mathrm{m}$. (Aiii) Prolonged

This article is protected by copyright. All rights reserved. 
incubation increased the average number of TBEV labelled vesicles per cell and also the average number of vesicles co-labelled with TBEV and EEA1. Black bars - TBEV labelled vesicles, white bars TBEV and EEA1 co-labelled vesicles, ${ }^{*} P<0.05$. (Bi,ii) An astrocyte with DiD-labelled TBEV vesicles (TBEV) incubated at $37{ }^{\circ} \mathrm{C}$ for $4 \mathrm{~h}$ and $18 \mathrm{~h}$ and with LAMP1-labelled lysosomes (LAMP1-lysosomal associated membrane protein 1). Overlays represent overlapped TBEV and LAMP1 fluorescent signals, indicating the association between TBEV and lysosomes. Bars: $5 \mu \mathrm{m}$. (Biii) Prolonged incubation increased the average number of TBEV labelled vesicles per cell and the average number of vesicles co-labelled with TBEV and LAMP1. Black bars - TBEV labelled vesicles, white bars - TBEV

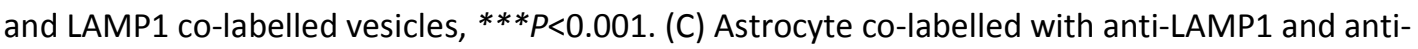
EEA1. In a single, $1 \mu \mathrm{m}$ thick optical slice, lysosomes and early endosomes appear to be largely different in size due to different position in z-axis and variable antibody attachments. Arrowheads point to large late lysosomes (LAMP1) and early endosomes (EEA1). Bar (bar inset): $5 \mu \mathrm{m}(2.5 \mu \mathrm{m}) . \mathrm{n}$ $(n)=$ number of cells (number of vesicles). Reprinted with permission ${ }^{117}$.

Figure 3 Secretory vesicles studied by STED and SIM microscopies in acutely isolated rat astrocytes.

(A) Confocal and STED microscopy images of immunostained D-serine-, V-GLUT1-, ANP- and BDNF-positive vesicles in acutely isolated astrocytes. Histograms display STED-acquired vesicle diameter distributions for 1788 (D-serine), 6787 (V-GLUT1), 1747 (ANP) and 798 (BDNF) vesicles (2 cells per staining). The black curves show Gaussian fits of the diameter distributions; the numbers next to the distribution peaks indicate the average vesicle diameter (expectation value \pm SEM). Recalculated values taking into account the microscope's optical resolution $(45 \mathrm{~nm})$ are $80.8 \mathrm{~nm}$ for Dserine, $88.4 \mathrm{~nm}$ for V-GLUT1, $85.9 \mathrm{~nm}$ for ANP and $86.8 \mathrm{~nm}$ for BDNF. Scale bar, $500 \mathrm{~nm}$.

(B) Wide-field microscopy and SIM were used to determine the vesicle diameter of immunostained LAMP1 endolysosomes and ATP-loaded vesicles (quinacrine dihydrochloride). Histograms show SIM-acquired vesicle diameter distributions for 557 (LAMP1, 2 cells) and 445 (quinacrine, 2 cells) vesicles in acutely isolated astrocytes (upper two panels) and 338 (LAMP1, 3 cells) and 333 (quinacrine, 6 cells) vesicles in astrocytes isolated from 7- to 8-week-old rats (lower two panels). The black curves show Gaussian fits of the diameter distributions; the average vesicle diameter (expectation value \pm SEM) is labelled next to the distribution peaks. Scale bar, $500 \mathrm{~nm}$. Modified with permission ${ }^{83}$.

This article is protected by copyright. All rights reserved. 

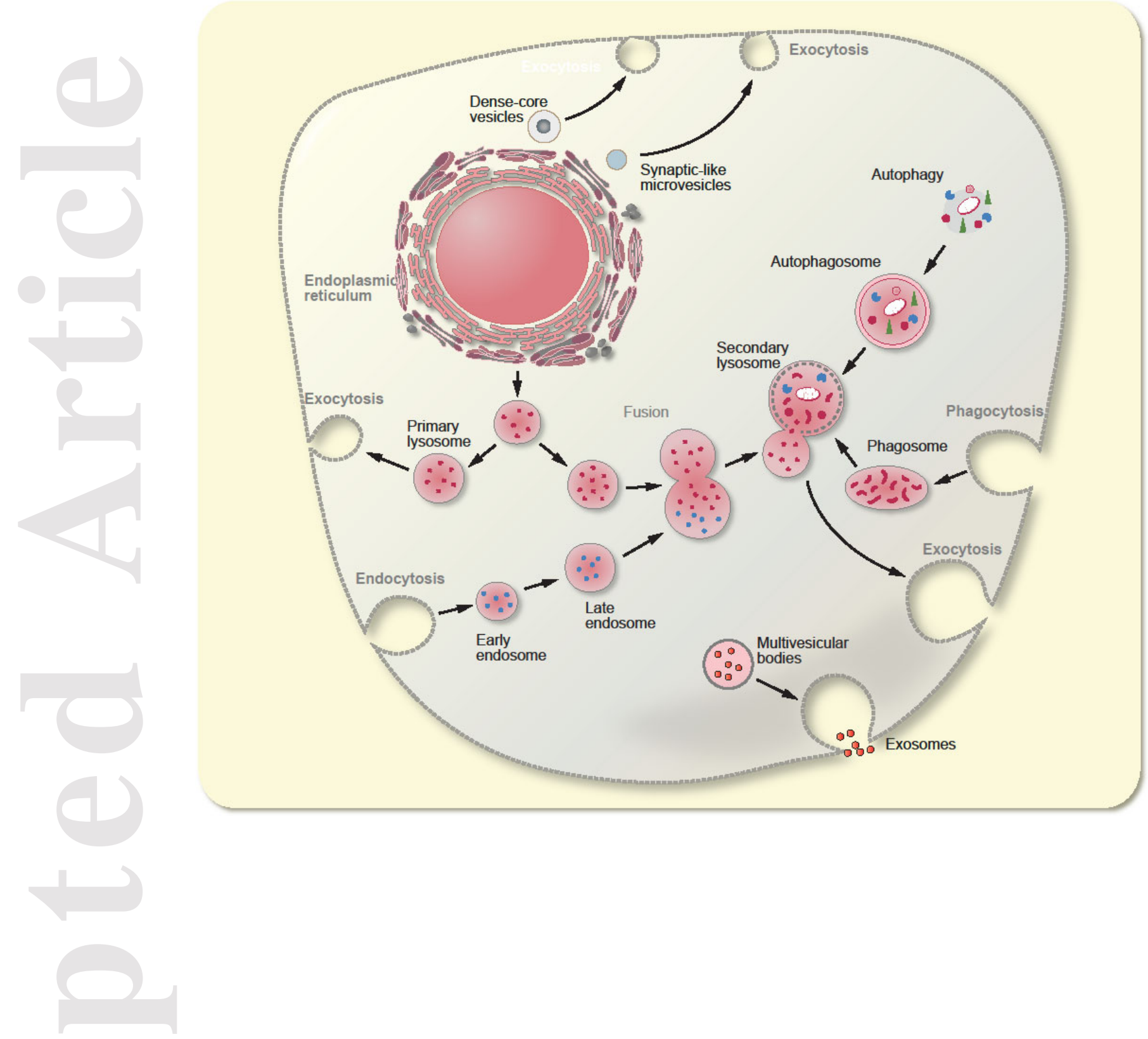

This article is protected by copyright. All rights reserved. 

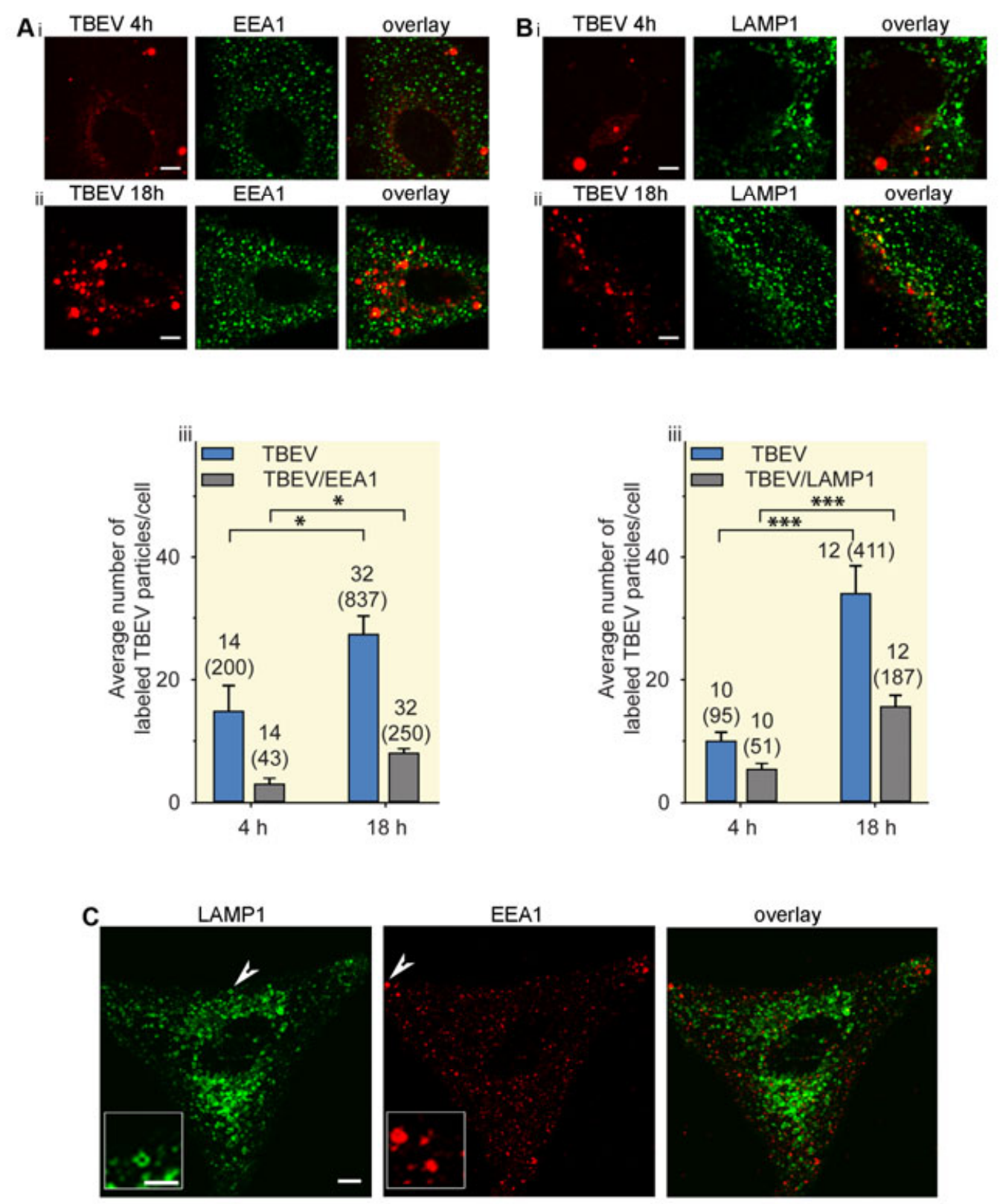

This article is protected by copyright. All rights reserved. 

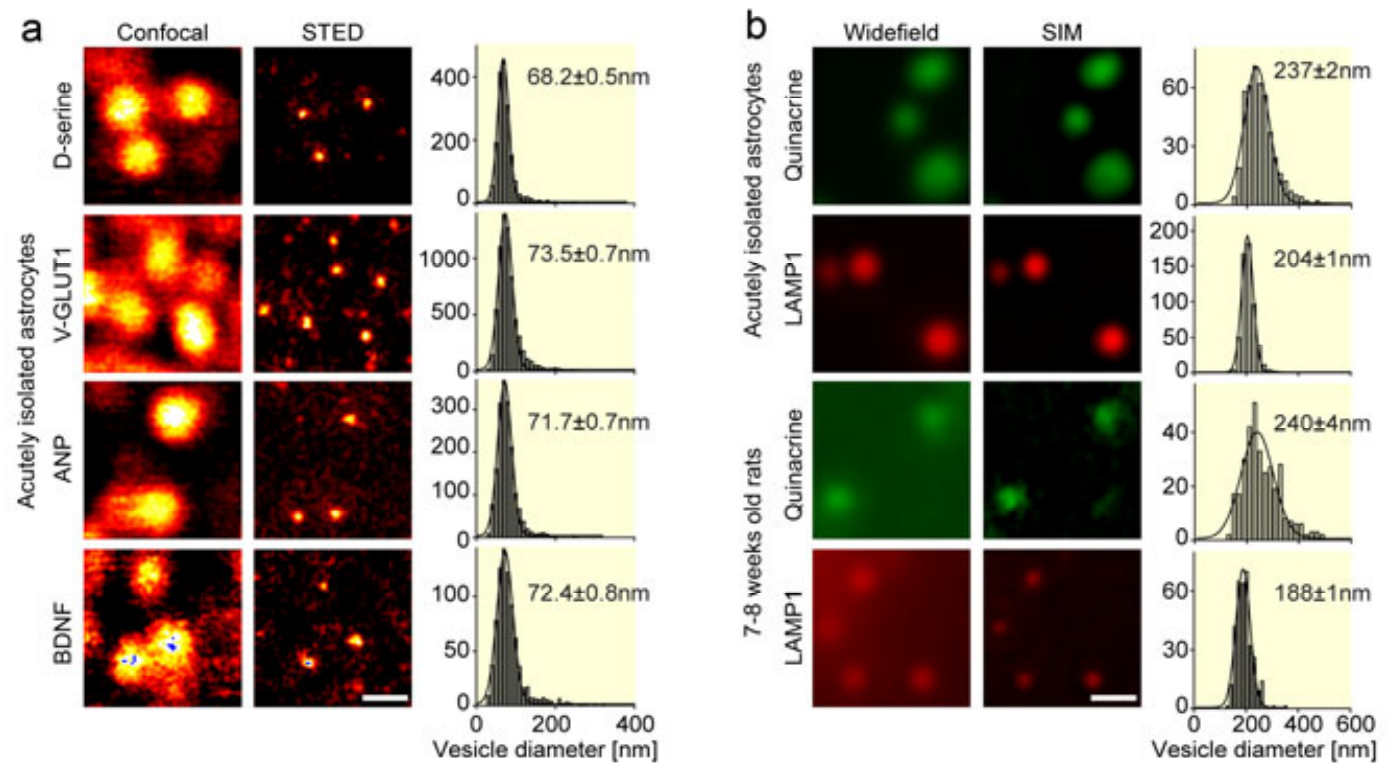

This article is protected by copyright. All rights reserved. 